\title{
Tailoring Ovarian Cancer Treatment: Implications of BRCA1/2 Mutations
}

\author{
Ainhoa Madariaga, Stephanie Lheureux and Amit M. Oza * \\ Division of Medical Oncology \& Hematology, Princess Margaret Cancer Center, Toronto, ON M5G 2M9, Canada; \\ ainhoa.madariaga@uhn.ca (A.M.); stephanie.lheureux@uhn.ca (S.L.) \\ * Correspondence: amit.oza@uhn.ca
}

Received: 5 February 2019; Accepted: 18 March 2019; Published: 23 March 2019

\begin{abstract}
High grade serous ovarian cancer (HGSOC) is the most common epithelial ovarian cancer, harbouring more than $20 \%$ germline or somatic mutations in the tumour suppressor genes BRCA1 and $B R C A 2$. These genes are involved in both DNA damage repair process via homologous recombination (HR) and transcriptional regulation. BRCA mutation confers distinct characteristics, including an increased response to DNA-damaging agents, such us platinum chemotherapy and poly-ADP ribose polymerase inhibitors (PARPi). However, several mechanisms of resistance to these agents have been described, including increased HR capacity through reverse $B R C A$ mutations, non-homologous end-joint (NHEJ) repair alterations and drug efflux pumps. Current treatments of ovarian cancer including surgery, chemotherapy, targeted treatment and maintenance strategies, as well as resistance mechanisms will be reviewed, focusing on future trends with respect to $B R C A$ mutation carriers.
\end{abstract}

Keywords: ovarian cancer; $B R C A$ mutation; homologous recombination; treatment; platinum; PARP inhibitor; resistance

\section{Introduction}

Contemporary cancer statistics highlight that ovarian cancer (OC) remains the most lethal gynecological malignancy in developed countries [1]; it is the seventh most common cancer in women worldwide, accounting for nearly $4 \%$ of all new cases of female cancers [2]. Approximately $90 \%$ of all OC cases are epithelial and fall within five distinct subtypes-high and low grade serous, endometrioid, clear cell and mucinous carcinomas [3,4]. Of these, high grade serous ovarian cancer (HGSOC) is the most common subtype, often diagnosed in Stage III (51\%) and IV (29\%), when disease has spread beyond the peritoneum leading to a modest 5 -year-cause specific survival of $42 \%$ and $26 \%$, respectively [5].

Standard front-line treatment for advanced OC has remained cytoreductive surgery with the goal of no residual disease (R0), followed by the combination of platinum and taxane chemotherapy. Response to front-line therapy helps define predictive response to second-line and subsequent therapies as OC typically follows a response-relapse pattern behavior. Therefore, at the time of recurrence, the platinum free interval (PFI) - time between the last dose of platinum based therapy and recurrence-is used to guide treatment decision [6,7]. OC is classified as platinum resistant if relapse occurs within six months and considered platinum sensitive if relapse occurs beyond six months [6-8]. This definition has been updated following the Fifth Ovarian Cancer Consensus Conference to therapy-free interval (TFI) [9]. TFI now includes delineation of type of therapeutic intervention in subsequent lines of therapy such as TFIp (PFI—platinum free interval), TFInp (non-PFI) and TFIb (biologic agent-free interval) and incorporates consideration of histology, BRCA1/2 mutation status $(B R C A \mathrm{~m})$, number/type of previous therapies, outcome of prior surgery and reported symptoms [9]. 
Incorporating these elements is critical as it is well appreciated that whilst some genomic characteristics may be shared across subtypes, disease biology and preponderance of mutations/alterations are distinct between OC subtypes. HGSOC are characterized by ubiquitous TP53 mutations, and significant focal DNA copy number alterations [10], while low grade serous OC is defined as TP53 wild-type [11]. Approximately 15-20\% of HGSOCs may be inherited with the most common germline mutations related to alterations in breast cancer 1 (BRCA1) and breast cancer 2 (BRCA2) genes [10]. The frequency and type of mutations differs among populations [12]; with the highest frequency being reported in Ashkenazi Jewish population, up to $2 \%$ of germline founder $B R C A 1 / 2$ mutations [13]. BRCA1 mutations are more common than $B R C A 2$ in OC, although the ratio of $B R C A 1$ to $B R C A 2$ varies between populations [12]. A cohort study with 445 women did not find an association between ethnicity, likelihood of having breast or ovarian cancers and overall survival (OS) [14]. In addition, somatic BRCA1/2m can be identified in $\sim 3 \%$ HGSOC, not related to germline mutation [10]. More broadly, defects in homologous recombination (HR), which is involved in repair of DNA damage and DNA replication, are common in HGSOC and detected in $~ 50 \%$ of the patients $[10,15]$. This review will focus on HGSOC treatment and potential differences associated with BRCAm status.

\subsection{BRCA1/2 Mutations, HR Genes and High Grade Serous Ovarian Cancer}

$B R C A 1$ and $B R C A 2$ genes are located on chromosomes 13 and 17, respectively. They are classified as tumour suppressors and are implicated in double strand DNA (dsDNA) break repair via HR to maintain genomic integrity. Additionally, $B R C A 1 / 2$ are involved in transcriptional co-regulation, chromatin remodeling and cell cycle control. Cells lacking BRCA accumulate chromosomal abnormalities, resulting in chromosomal instability $[16,17]$. Germline BRCA1/2 mutations (gBRCAm) confer an increased risk of breast and HGSOC, and, to a lesser extent, of other type of cancers such as certain pancreatic [18], prostate [19], stomach and colon cancers [20]. A meta-analysis involving 22 studies with $>8000$ cases showed that the average cumulative risk for OC by the age of 70 was $39 \%$ and $11 \%$ in BRCA1m and BRCA2m carriers, respectively [21]. However, the majority of HGSOC are sporadic, and a proportion of these will have alteration in BRCA function through somatic mutations in BRCA1/2 genes or as a result of methylation [10].

In addition to $B R C A 1 / 2$, other germline HR related mutations have been identified in up to $\sim 6 \%$ of HGSOC from a case series [22]. The Fanconi Anemia pathway controls DNA repair via HR, and several genes in this pathway, such as BRIP1, RAD51C and RAD51D are established to increase HGSOC risk. Other germline HR genes might be involved in hereditary OC including RAD50, CHEK2, PALB2, BARD1, NBN and MRE11 [22,23]. Lynch syndrome, characterized by germline mutations in mismatch repair genes (MLH1, MSH2, MSH6, PMS2) or EPCAM (implicated in post-replicative proof-reading and genome integrity) [24], has been identified as responsible for $10-15 \%$ of hereditary OC cases, predominantly endometrioid $[25,26]$.

Patients with $\mathrm{g} B R C A \mathrm{~m}$ are younger at presentation and diagnosis [27,28]. A meta-analysis showed that women with $B R C A \mathrm{~m}$ (not specified if somatic mutation carriers are included) OC have an increased OS (BRCA1: HR 0.76, 95\% CI: 0.70-0.83; BRCA2: HR: 0.58, 95\% CI: 0.50-0.66), regardless of tumour stage, grade, or histologic subtype [29]. However, this remains controversial as a large Canadian series showed that although there is an initial survival advantage among gBRCAm carriers, it was not a predictor of long-term survival at 10 years [30]. Although $B R C A 1$ and $B R C A 2$ are intimately involved in DNA damage repair; specific roles of $B R C A 1$ and $B R C A 2$ are unique and distinct [31]. As a result, published work illustrates potential differences in survival and response to treatment dependent on $B R C A 1$ or $B R C A 2$ mutation. Several reports have suggested $B R C A 2 \mathrm{~m}$ patients have a survival advantage and increased response to platinum-based chemotherapy compared to those with $B R C A 1 \mathrm{~m}[32-35]$. 


\subsection{Ovarian Cancer Screening and Prevention in BRCA1/2 Mutation Carriers}

Screening has been relatively ineffective and no screening strategies in OC have been found to decrease mortality [36,37]. Given the lack of success of screening procedures, risk-reducing salpingo-oophorectomy remain the gold standard [37].

Pharmacological and surgical prevention strategies have been explored in $\mathrm{g} B R C A \mathrm{~m}$ carriers. A case-control study found reduced risk of OC in women taking oral contraceptives compared to women who did not (BRCA1: odds ratio 0.56, $p<0.0001 ; B R C A 2$ : odds ratio 0.39, $p=0.0004$ ) [38]. Studies assessing anti-inflammatory drugs such as aspirin in $\mathrm{g} B R C A \mathrm{~m}$ carriers are currently ongoing (NCT03480776). Risk-reducing surgical strategies include salpingo-oophorectomy and salpingectomy, which allows the preservation of ovarian function. A prospective observational study showed that oophorectomy or salpingo-oophorectomy reduced the risk of OC by $80 \%$ [39]. A Cochrane meta-analysis including ten cohort studies and 8087 BRCAm carriers concluded with very-low certainty evidence that risk-reducing sapingo-oophorectomy reduces risk of death from OC [40]. A large cohort study found reduced risk of OC with tubal-ligation in BRCA1/2 mutation carriers (HR, $0.43 ; 95 \%$ CI, $0.24-0.75 ; p=0.003$ ) [41]. A meta-analysis where the prior cohort study was excluded, showed a trend towards reduced risk of $O C$ with tubal-ligation in $B R C A 1$ mutation carriers (odds ratio $0.69, p=0.098$ ), but not in $B R C A 2$ mutation carriers (odds ratio $0.73, p=0.33$ ), likely due to small number [42]. A proof-of-concept observational study is assessing the safety of salpingectomy with delayed oophorectomy (NCT01907789).

\section{Treatment of Ovarian Cancer \& Implications of BRCA1/2 Status}

\subsection{Surgery}

Primary surgery is one of the mainstream treatments of OC. Optimal cytoreduction in OC cancer is associated with an OS benefit [43]. Retrospective studies have shown that $\mathrm{g} B R C A \mathrm{~m}$-associated and sporadic HGSOC have similar rates of primary optimal debulking [44]; however, those harboring $\mathrm{g} B R C A \mathrm{~m}$ have been linked to higher peritoneal tumour load, reduced frequency of ovarian masses and increased bulky lymph nodes at diagnosis [45]. Furthermore, there are morphologic differences (micropapillary architecture and pushing pattern) in the metastases of gBRCAm HGSOC with different characteristics of disease spread compared to sporadic HGSOC [46].

At tumour relapse, secondary surgical cytoreduction is recommended in selected platinum sensitive recurrences. Selection criteria include optimal primary surgery, absence of ascites, tumour resectability and good performance status [47]. Although there is contradictory data, secondary cytoreduction has been associated with a progression free survival (PFS) benefit when patients are well selected, but no overall survival (OS) benefit has been demonstrated $[47,48]$. Outcome improvement is linked to the absence of residual disease post debulking surgery. $B R C A 1 / 2$ status has not been determined as a factor influencing the outcome of secondary cytoreductive surgery and is not incorporated in the surgical scores to predict an optimal cytoreduction [47-52]. gBRCAm carriers have also been linked with an increase of visceral metastases at relapse, which makes secondary surgeries more challenging [53].

\subsection{Intraperitoneal (IP) Chemotherapy}

OC tends to metastasize but remains often confined into the surface of the peritoneal cavity. A higher concentration of drug as well as a slower clearance from the peritoneum is achieved with intraperitoneal chemotherapy [54]. Frontline intraperitoneal chemotherapy can be used in stage III HGSOC treatment following surgery, in patients with complete cytoreduction or residual disease $<1 \mathrm{~cm}$ [55-57]. Mature data from over 10 years and three meta-analyses have demonstrated an OS benefit comparing IP to intravenous chemotherapy; although, the debate remains given new options and concerns regarding design of past studies and toxicity [58-61]. Among patients participating in GOG-172 randomised phase III study aberrant BRCA1 expression, assessed by immunohistochemistry, was detected in $52 \%$ of the women, and correlated with increased OS in those treated with IP 
chemotherapy vs. intravenous chemotherapy (84 vs. 47 months; $p=0.0002)[56,62]$. Given the BRCA assessment technique limitations, further studies where $B R C A$ sequencing is performed are needed to validate these findings.

More recently, the addition of hyperthermic intraperitoneal chemotherapy (HIPEC) with cisplatin to interval cytoreductive surgery, following 3 cycles of neoadjuvant chemotherapy, was shown to increase recurrence-free survival (10.7 vs. 14.2 months; HR 0.66, $p=0.003$ ) and OS (33.9 vs. 45.7 months; HR $0.67, p=0.02$ ) in stage III epithelial OC in a phase III randomised trial. Results remain controversial due to statistical considerations given the small sample size and absence of stratification according to $B R C A 1 / 2$ status and histological subtype [63]. Although BRCAm was not assessed in this study, there is retrospective data suggesting a possible increase in efficacy in this population [64]. In fact, at the cellular level hyperthermia inhibits HR DNA repair, through degradation of BRCA2. Hyperthermia is a potential enhancer of the efficacy of DNA-damaging agents, such as intraperitoneal platinum and poly ADP-ribose polymerase inhibitors (PARPi); although, these findings need to be confirmed [65-67].

\subsection{Intravenous (IV) Chemotherapy}

\subsubsection{Platinum}

Platinum chemotherapy remains the backbone of HGSOC treatment. Platinum salts bind to nuclear DNA, forming a variety of structural adducts and trigger cellular responses to DNA damage, replication and transcription inhibition, cell cycle arrest and apoptosis [68,69]. Carboplatin and paclitaxel combination regimen is the well-established standard first-line treatment in advanced OC $[70,71]$ and at the time of relapse for OC patients who are considered platinum sensitive [72-74].

The impairment of DNA repair processes caused by BRCA1/2 mutations is a key mechanism involved in the enhanced response to platinum chemotherapy damage [75]. In vitro studies have shown increased sensitivity to platinum agents in cells harboring BRCAm, likely due to a loss of $B R C A$ mediated DNA damage response and DNA repair [76,77]. A small interfering RNA screen to identify gene enhancers of chemotherapeutic agents showed that silencing of $B R C A 1 / 2$ potentiates cisplatin cytotoxicity [78]. Similarly, an increased sensibility to platinum chemotherapy has been found in BRCAm breast and OC xenografts $[79,80]$. Consistent with these pre-clinical findings, women with $\mathrm{gBRCAm}$ OC have a higher response rate (RR) to platinum-based chemotherapy. Several series have found that the majority of $B R C A \mathrm{~m}$ women achieve partial or complete responses with platinum agents [81-84]. Interestingly, even in the setting of platinum resistant disease there may be a role of considering rechallenge with platinum chemotherapy in gBRCAm carriers. A case-control study also showed high responses to platinum chemotherapy in platinum resistant $\mathrm{g} B R C A \mathrm{~m}$ patients, with a CA125 decrease of $80 \%$ vs. $43.6 \%$, in comparison to non gBRCAm carriers [83]. Patients who are germline $B R C A$ wildtype (gBRCAwt) but respond to several lines of chemotherapy are more likely to harbor somatic BRCAm (sBRCAm) [83].

Although the numbers are too small, and direct comparisons between $B R C A 1$ and $B R C A 2$ have not been conducted, a 316 patient cohort study suggested that $B R C A 2 \mathrm{~m}$ has an increased response to first-line chemotherapy in comparison to BRCAwt and BRCA1m patients [35]. This may be explained by the distinct role of $B R C A 2$ in DNA repair, regulating RAD51 protein, which is required for ds-DNA break repair [85]. The presence of HR mutations other than $B R C A$, has also been found to be predictive of primary platinum sensitivity [86].

\subsubsection{Non Platinum Chemotherapy}

\section{Taxanes}

Taxanes are microtubule stabilizing agents that interfere with the formation of mitotic spindles, causing cell cycle arrest and ultimately apoptosis [87]. For example, paclitaxel is an effective treatment for OC in the first-line in combination with platinum agents and in relapsed settings as monotherapy. 
A phase III study showed a better outcome with the combination of paclitaxel-cisplatin regimen than for those on a combination with cyclophosphamide [88]. Paclitaxel is also one of the most active non-platinum drugs used as monotherapy in recurrent OC [89-91]. The drug can be administered three weekly or weekly, showing a potential 'anti-angiogenic' effect when using the weekly regimen [92]. A phase III study comparing three weekly carboplatin and paclitaxel to three weekly carboplatin and dose dense weekly paclitaxel as front line treatment in Japanese women showed improvement in progression free survival and overall survival with the combination dose dense regimen (PFS HR 0.76, $p=0.0037$; OS HR 0.79, $p=0.039$ ), which was not confirmed in European studies (MITO-7 three weekly vs. weekly carboplatin and paclitaxel PFS: HR $0.96, p=0.66$; ICON-8 three weekly carboplatin and paclitaxel (arm1) vs. three weekly carboplatin and weekly paclitaxel (arm2) vs. weekly carboplatin and paclitaxel (arm 3) PFS: arm 2 vs. 1 HR $0.92 p=0.45$, arm 3 vs. 1 HR 0.94, $p=0.56$ ), though one of these (MITO-7 trial) reduced dose density of paclitaxel and also gave carboplatin on a weekly basis [93-95]. Similarly, another European randomised phase III study on paclitaxel monotherapy failed to note any differences in the two administration types [96]; however, the dose dense regimen is well established in platinum resistant recurrent disease. To date, there remains no available clinical data regarding the implication of $B R C A \mathrm{~m}$ in dose dense delivery of taxanes.

Inhibition of BRCA1 expression in OC cell lines has been shown to reduce anti-tumour activity of taxanes, due to differential regulation of apoptosis by BRCA1 protein [76]. The effect of BRCA2 in taxane resistance is less studied. A cell-line study on BRCA2m and TP53wt OC showed high sensitivity to taxanes and platinum agents [77] although the clinical relevance of these findings is unclear and with limited retrospective data available suggesting no difference in response according to $B R C A 1 / 2$ status [97]. Retrospective studies do suggest lower response to taxanes in sBRCA2m prostate, and $B R C A 1 \mathrm{~m}$ breast cancer patients $[98,99]$. The relationship between taxane sensitivity and BRCAm in $\mathrm{OC}$ requires further investigation.

\section{Trabectedin}

Trabectedin is a DNA alkylating agent that binds to the DNA minor groove and modifies the tumour microenvironment by reducing the pro-inflammatory mediators. The sensitivity to trabectedin is linked to an efficient transcription-coupled nucleotide excision repair and deficient HR repair activity in the target tumour cells [100,101].

A phase III study including platinum sensitive and resistant patients, showed PFS improvement (7.3 vs. 5.8 months; HR $0.79 p=0.019$ ), without OS benefit for the combination of trabectedin and pegylated liposomal doxorubicin (PLD), versus single agent PLD [102]. Subgroup analyses suggested a trend towards OS benefit in the platinum sensitive cohort (HR 0.85, $p=0.092$ ), which was particularly enhanced in the partial platinum sensitive population with a PFI of 6-12 months (23 vs. 17.1 months; HR $0.59 p=0.0015$ ). This finding led the European Medicines Agency (EMA) to approve trabectedin combined with PLD in patients with relapsed, platinum sensitive OC $[103,104]$. Subgroup analyses also


III study comparing the experimental arm of PLD with trabectedin versus PLD with carboplatin in partial platinum sensitive OC (NCT01379989) are pending.

A single-arm phase II study in patients with BRCAm or BRCAness phenotype (repeated platinum-sensibility), showed high RR to trabectedin (Overall response rate (ORR) 39.4\%; platinum sensitive $47.8 \%$, platinum resistant $31.2 \%$ ), with no statistically significant difference according to the mutational status [106].

Pegylated Liposomal Doxorubicin (PLD)

Doxorubicin is a cytotoxic anthracycline that produces DNA damage, inhibiting DNA topoisomerase II. The topoisomerase II-doxorubicin-DNA complex has been shown to induce dsDNA breaks. In the case of PLD, the pegylated liposomal coating provides stabilization in blood as well as 
increased blood circulation time, achieving increased accumulation in tumours with high vascular permeability [107].

PLD has activity in OC, when used in combination with carboplatin in the setting of platinum sensitive recurrence [108], or as monotherapy in platinum resistant disease [109,110]. The combination of carboplatin and PLD failed to show superiority in comparison to carboplatin and paclitaxel in first-line setting, but it did show equal efficacy in platinum sensitive recurrent disease with a favorable toxicity profile [111,112].

Given the mechanism of effect of PLD in DNA repair, BRCAm OC might have an increased sensitivity to this agent. Retrospective data shows increased response to PLD in patients with BRCAm $[97,113,114]$. A randomised phase II study on $g B R C A m$ OC patients who recurred prior to 12 months since the last platinum-based chemotherapy, compared PLD to single agent olaparib and showed no differences in PFS (HR 0.88, $p=0.66$ ) [115]. This was one of the first trials that restricted eligibility to women with $\mathrm{gBRCAm}$ ovarian cancer, with partially platinum sensitive and platinum resistant disease; as a consequence, the median PFS of the PLD arm was higher than had been predicted at 7.1 months, and explained as perhaps an non-anticipated consequence of the enrichment strategy, due to exclusion of women without gBRCAm and other histologic subtypes which are more resistant (clear cell, mucinous) [109,110,115].

\subsection{Targeted Treatment}

\subsubsection{PARP inhibitor (PARPi)}

Poly(ADP-ribose) polymerases (PARPs) are enzymes that transfer ADP-ribose groups to target proteins. They function in cellular signaling pathways, including DNA repair, transcriptional regulation, RNA interference, mitochondrial function, formation of subnuclear bodies and in cell division [116]. In humans, there are 17 members of the PARP gene family, with PARP-1 and PARP-2 being the most studied due to their involvement in DNA damage detection and repair [117]. As a result of DNA single strand breaks (SSBs), a process called PARylation occurs whereby PARP-1 and PARP-2 produce large branched chains of ADP-ribose polymers from nicotinamide adenine dinucleotide (NAD+). Subsequently these polymers directly participate or coordinate the repair process, including the base excision repair (BER) [118].

The rationale for the development of PARP inhibitors (PARPi) was based on the concept of synthetic lethality, whereby mutations in two genes are synthetic lethal, but a mutation of one alone maintains viability of cells (Figure 1) [119]. PARP1 is involved in the SSBs but is not a major determinant in dsDNA repairs [120]; although a persistent damage in SSBs may cause the collapse of the replication forks, producing DSBs, which are commonly repaired by HR enzymes [121]. Thus, cancer cells with $B R C A m$ treated with PARPi accumulate SSBs, leading to DSBs that are not repaired by the HR pathway, ultimately resulting in cell cycle arrest or death [122].

PARPi have been evaluated as single-agents, in combination and as maintenance treatment following response to platinum-based chemotherapy in OC. Olaparib is the most investigated PARPi and the first agent approved by the European and American regulatory agencies. Several PARPi have now also been approved due to level 1 evidence in ovarian cancer including niraparib and rucaparib. Talazoparib was recently approved by the U.S. Food and Drug Administration (FDA) for gBRCA, HER2 negative breast cancer. 


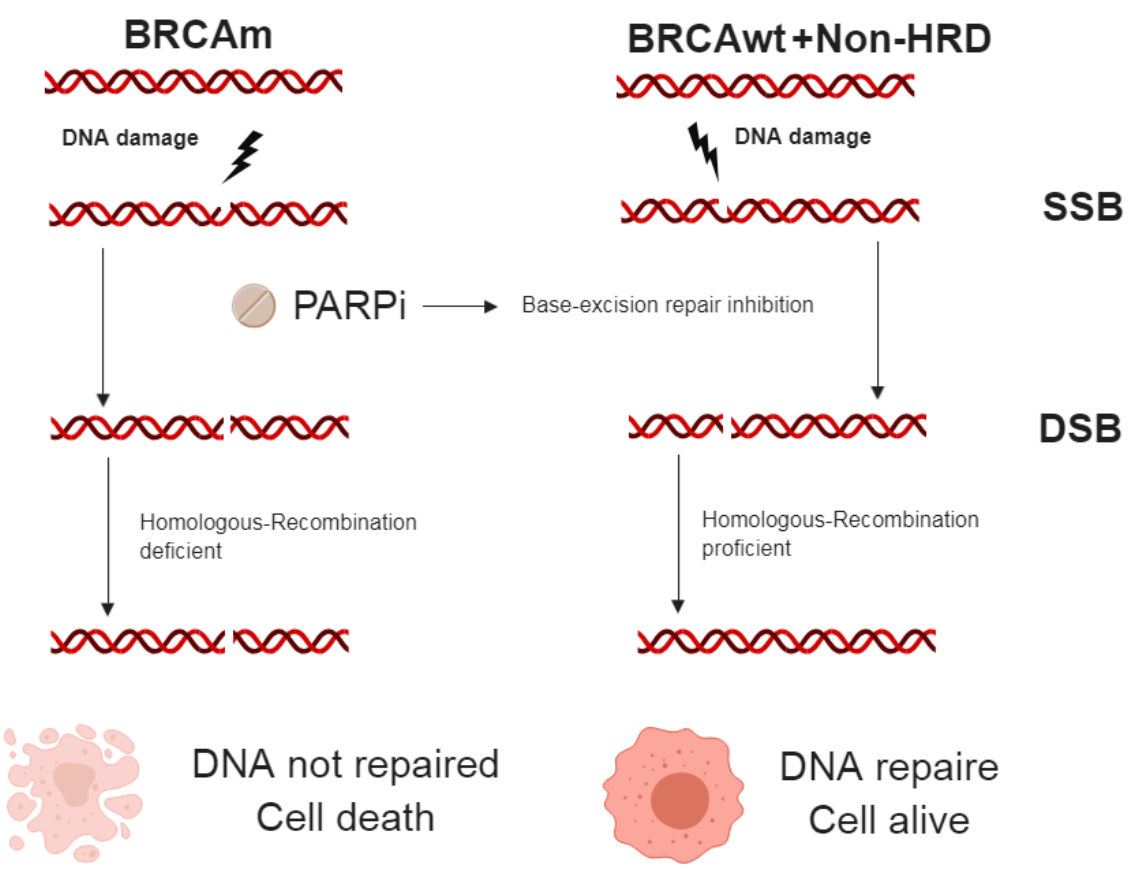

Figure 1. Synthetic lethality concept [119]. A DNA damage can lead to a single-strand break (SSB), and PARP enzymes play an essential role in SSB repair. The administration of PARPi will inhibit base-excision repair for SSB. If SSB are not repaired, continuous damage can progress to double-strand breaks (DSB). DSBs are usually repaired through the BRCA dependent homologous-recombination process. However, in cells with $B R C A m$ the homologous-recombination pathway for DSB repair is damaged and leads to cell death. BRCAm: BRCA mutation, $B R C A w \mathrm{t}: B R C A$ wildtype, Non-HRD: No homologous recombination deficiency, SSB: single strand break, DSB: double strand break.

Single Agent Treatment

Several phase I and II trials have been published on single agent PARPi focusing on BRCAm population (Table 1). Gelmon et al. demonstrated activity of olaparib in women without BRCAm and the influence of platinum sensitivity or resistance. Kaufman et al. showed in a phase II trial that olaparib is effective as treatment across different tumour types with $\mathrm{g} B R C A 1 / 2 \mathrm{~m}$. In the OC cohort, 193 heavily pretreated women, either platinum resistant or non-suitable for platinum, were included, showing an ORR of $31.1 \%[123,124]$. This study led to the FDA approval of olaparib in BRCAm OC treated with three or more lines of chemotherapy [125].

Data across different PARPi used as single agent suggest that RR are higher in BRCAm population. In Part 1 of ARIEL2 (NCT01891344) clinical trial, women with recurrent platinum sensitive HGSOC were treated with rucaparib. A tumour-based molecular signature of HR deficiency (HRD) was developed, classifying patients according to $B R C A \mathrm{~m}$ and loss of heterozygosity $(\mathrm{LOH})$, representing HRD. PFS was significantly higher in the BRCAm (HR 0.27, $p<0.0001$ ) and LOH-high (HR 0.62, $p=0.011$ ) compared to LOH-low subgroup [126]. Data also suggests a higher activity of single agent PARPi in platinum sensitive population (Table 1) [127-133].

The activity of single agent PARPi has been compared to chemotherapy in a randomised phase II trial in women with platinum resistant and partially platinum sensitive disease, comparing two doses of olaparib with PLD in gBRCAm OC, showing no statistical significant differences in PFS (HR 0.88, $p=0.66)[115]$. 
Table 1. Phase 1-2 trials assessing single agent PARP inhibitors. N: number of patients. NR: Not reported. PlatS: platinum sensitive. PlatR: platinum resistant. BID: twice daily. QD: Once daily. LOHh: High loss of heterozygosity, LOHl: Low loss of heterozygosity; LOHu: Unkown loss of heterozygosity. MMC: MitomicinC. IV: intra venous. PFI: platinum free interval.

\begin{tabular}{|c|c|c|c|c|c|c|c|}
\hline & Phase & $\mathrm{N}$ (Ovarian) & Prior Treatments & $\begin{array}{l}B R C A / H R \\
\end{array}$ & Platinum Sensitivity & Dosage & RR (RECIST 1.1) \% CI 95\% \\
\hline \multicolumn{8}{|c|}{ OLAPARIB } \\
\hline $\begin{array}{l}\text { Fong et al. [127] } \\
\text { (NCT00516373) }\end{array}$ & Phase 1 & 50 & $\begin{array}{l}1: 10 \% \\
2: 22 \% \\
3: 22 \% \\
\geq 4: 46 \%\end{array}$ & $48 \mathrm{gBRCA \textrm {m }}(96 \%)$ & 13 Plats (27\%) & $\begin{array}{l}\text { Escalation: } 40 \mathrm{mg} \mathrm{qd}-600 \mathrm{mg} \text { bid. } \\
\text { Expansion: } 200 \mathrm{mg} \text { bid. }\end{array}$ & $\begin{array}{l}28 \%(16.2-42.5) \\
\text { Plats: } 46.2 \%(19.2-74.9) \\
\text { PlatR: } 33.5 \%(15.6-55.3) \\
\text { Plat Refractory: } 0 \%(0-24.7)\end{array}$ \\
\hline $\begin{array}{l}\text { Mateo et al. [134] } \\
\text { (NCT00777582) }\end{array}$ & Phase 1 Multitumour & Group 1 and $6(\mathrm{OC}): 53$ & $\begin{array}{l}\text { Group 1: median } 6(200 \mathrm{mg} \text { bid) } \\
\text { and } 3 \text { (400 } \mathrm{mg} \text { bid) } \\
\text { Group 6: median } 4 \text { ( } 300 \mathrm{mg} \text { bid) } \\
\text { and } 3 \text { (400 } \mathrm{mg} \text { bid) }\end{array}$ & $\begin{array}{l}\text { Group } 1 \text { and 6: } \\
53 \mathrm{gBRCA \textrm {m }}(100 \%)\end{array}$ & $\begin{array}{l}\text { Group 1: NR } \\
\text { Group 6: } 15 \text { PlatS (37\%) }\end{array}$ & $200-400 \mathrm{mg}$ bid. & $\begin{array}{l}\text { Group } 1 \text { and } 6: 30 \% \\
(18.3-44.3)\end{array}$ \\
\hline \multirow{2}{*}{$\begin{array}{l}\text { Audeh et al. [129] } \\
\text { (NCT00494442) }\end{array}$} & \multirow[b]{2}{*}{ Phase 2} & \multirow[b]{2}{*}{57} & \multirow{2}{*}{$\begin{array}{l}\text { Median } 3(400 \mathrm{mg} \text { bid) and } 4 \\
(100 \mathrm{mg} \text { bid })\end{array}$} & \multirow{2}{*}{$57 \mathrm{gBRCA \textrm {m }}(100 \%)$} & \multirow[b]{2}{*}{19 PlatS (33\%) } & $400 \mathrm{mg}$ bid & $\begin{array}{l}33 \%(20-51) \\
\text { PlatS: } 38 \% \\
\text { PlatR: } 30 \%\end{array}$ \\
\hline & & & & & & $100 \mathrm{mg}$ bid & $\begin{array}{l}\text { 13\% (4-31) } \\
\text { PlatS: } 50 \% \\
\text { PltR: NR }\end{array}$ \\
\hline $\begin{array}{l}\text { Gelmon et al. [128] } \\
\text { (NCT00679783) }\end{array}$ & $\begin{array}{l}\text { Phase } 2 \text { Ovarian and } \\
\text { breast cancer }\end{array}$ & 64 & Median 3 & 17 BRCAm $(26 \%)$ & 25 PlatS (38.5\%) & $400 \mathrm{mg}$ bid & $\begin{array}{l}\text { 29\% (19-41) } \\
\text { BRCAm: } \\
\text { PlatS: } 60 \% \\
\text { PlatR:33\% } \\
\text { BRCAwt/u: } \\
\text { PlatS: } 50 \% \\
\text { PlatR: } 4 \%\end{array}$ \\
\hline $\begin{array}{l}\text { Kaufman et al. [123] } \\
\text { (NCT01078662) }\end{array}$ & Phase 2. Multitumour & 193 & Mean 4.3 & 193 BRCAm $(100 \%)$ & All PlatR or intolerant. & $400 \mathrm{mg}$ bid & $31.1 \%(24.6-38.1 \%)$ \\
\hline \multirow{3}{*}{$\begin{array}{l}\text { Kaye et al. [115] } \\
\text { (NCT00628251) }\end{array}$} & \multirow{3}{*}{ Phase 2. Olaparib vs. PLD } & \multirow{3}{*}{97} & Olaparib 200 mg: $\geq 3$ lines: 59\% & \multirow{3}{*}{$97 \mathrm{BRCA \textrm {m }}(100 \%)$} & \multirow{3}{*}{48 PlatS } & $200 \mathrm{mg}$ bid & $25 \%$ \\
\hline & & & Olaparib $400 \mathrm{mg}: \geq 3$ lines: $78 \%$ & & & $400 \mathrm{mg}$ bid & $31 \%$ \\
\hline & & & PLD: $\geq 3$ lines: $51 \%$ & & & PLD & $18 \%$ \\
\hline \multicolumn{8}{|c|}{ NIRAPARIB } \\
\hline $\begin{array}{l}\text { Sandhu et al. [130] } \\
\text { (NCT00749502) }\end{array}$ & Phase 1 & 49 & Overall population median: 5 & 22 BRCAm (45\%) & 13 PlatS $(27 \%)$ & $\begin{array}{l}\text { Part A: } 30-400 \mathrm{mg} \mathrm{qd} \\
\text { Part B: } 300 \mathrm{mg} \mathrm{qd}\end{array}$ & $\begin{array}{l}\text { BRCAm: 40\% (19-64) } \\
\text { PlatS: } 50 \%(19-81) \\
\text { PlatR: } 33 \%(7-70) \\
\text { BRCAwt: NR } \\
\text { Plats: } 33 \%(1-91) \\
\text { PlatR: } 5 \%(<1-26)\end{array}$ \\
\hline $\begin{array}{l}\text { Moore et al. [135] } \\
\text { QUADRA (NCT02354586) } \\
\text { Abstract }\end{array}$ & Phase 2 & 463 & All patients $\geq 3$ prior lines & NR & $\begin{array}{l}162 \text { Plat refractory } \\
152 \text { PlatR } \\
118 \text { PlatS } \\
31 \text { U }\end{array}$ & $300 \mathrm{mg} \mathrm{qd}$ & $\begin{array}{l}\text { HRD: } \\
\text { PlatS 27.5\% (15.9-41.7) } \\
\text { BRCAm: } 38.9 \%(7-18) \\
\text { BRCAwt: } 21.2 \%(7-33) \\
\text { Non-HRD: NR. }\end{array}$ \\
\hline
\end{tabular}


Table 1. Cont

\begin{tabular}{|c|c|c|c|c|c|c|c|}
\hline & Phase & $\mathrm{N}$ (Ovarian) & Prior Treatments & $B R C A / H R$ & Platinum Sensitivity & Dosage & RR (RECIST 1.1) \% CI 95\% \\
\hline \multicolumn{8}{|c|}{ RUCAPARIB } \\
\hline $\begin{array}{l}\text { Drew et al. [136] } \\
\text { (NCT00664781) }\end{array}$ & Phase 2. OC and breast cancer & 51 & Overall population: median 2 & 47 BRCAm $(92 \%)$ & NR & $\begin{array}{l}\text { IV }\left(4-18 \mathrm{mg} / \mathrm{m}^{2}, 5 \text { days } \mathrm{q} 3 \mathrm{w}\right) \\
\text { Oral }(92 \mathrm{qd}-600 \text { bid). }\end{array}$ & $\begin{array}{l}\text { Overall population OC + } \\
\text { breast: } 7 \% \text {. } \\
\text { IV cohort: } 2 \% \\
\text { Oral cohort: } 15 \%\end{array}$ \\
\hline \multirow{2}{*}{$\begin{array}{l}\text { Kristeleit et al. [137] } \\
\text { STUDY } 10 \text { (NCT01482715) }\end{array}$} & \multirow{2}{*}{ Phase 1-2. Multitumour } & $\begin{array}{l}\text { Part 1: } 20 \mathrm{OC} \\
\text { (multi-tumour) }\end{array}$ & Overall population: Median 4 & $\begin{array}{l}\text { Part 1: Overall } \\
\text { population } 64 \%\end{array}$ & $\begin{array}{l}\text { Part 1: Overall } \\
\text { population } 14.3 \%\end{array}$ & Part 1: $40 \mathrm{mg} \mathrm{qd}-840 \mathrm{mg}$ bid & Part 1: NR \\
\hline & & $\begin{array}{l}\text { Part 2A: } 42 \text { (only } \\
\text { ovarian) }\end{array}$ & Median 2 & $\begin{array}{l}\text { Part 2A: } 42 \text { BRCAm } \\
(100 \%)\end{array}$ & Part 2A: 42 PlatS. (100\%) & Part 2A: $600 \mathrm{mg}$ bid. & Part 2A: 59.5\% (43.3-74.4) \\
\hline $\begin{array}{l}\text { Swisher et al. [126] ARIEL } \\
2 \text { part } 1 \text { (NCT01891344) }\end{array}$ & Phase 2 & 206 & $\begin{array}{l}\text { BRCAm: } \geq 2 \text { lines } 58 \% \\
\text { LOHh, BRCAwt: } \geq 2 \text { lines } 46 \% \\
\text { LOHl, BRCAwt: } \geq 2 \text { lines } 33 \% \\
\text { LOHu, BRCAwt: } \geq 2 \text { lines } 17 \%\end{array}$ & $\begin{array}{l}40 \text { BRCAm }(19 \%) \\
82 \mathrm{LOHh}(B R C A \mathrm{wt}) \\
70 \mathrm{LOHl}(B R C A \mathrm{wt}) \\
12 \mathrm{LOHu}(B R C A \mathrm{wt})\end{array}$ & 206 Plats (100\%) & $600 \mathrm{mg}$ bid & $\begin{array}{l}\text { BRCAm: } 80 \%(64-91) \\
\text { LOHh: } 29 \%(20-40) \\
\text { LOHl: } 10 \%(4-20) \\
\text { LOHu: } 33 \%(10-65)\end{array}$ \\
\hline $\begin{array}{l}\text { Oza et al. [131] Pool data: } \\
\text { ARIEL2+ STUDY } 10\end{array}$ & Phase 2 & $\begin{array}{l}106 \text { (integrated efficacy } \\
\text { population) }\end{array}$ & $\geq 3$ prior chemotherapies, $61.3 \%$ & $106 \mathrm{BRCAm}(100 \%)$ & 79 PlatS (74.5\%) & $600 \mathrm{mg}$ bid & $\begin{array}{l}53.8 \%(43.8-63.5) \\
\text { PFI > 12 m: 73.9\% } \\
\text { (51.6-89.8) } \\
\text { PFI 6-12 m: } 62.5 \% \\
\text { (48.5-75.1) } \\
\text { PFI < } \mathrm{m}: 18.5 \%(6.3-38.1)\end{array}$ \\
\hline \multicolumn{8}{|c|}{ VELIPAPRIB } \\
\hline $\begin{array}{l}\text { Coleman et al. [138] } \\
\text { (NCT01540565) }\end{array}$ & Phase 2 & 50 & $\begin{array}{l}1: 28 \% \\
2: 36 \% \\
3: 36 \% \\
\end{array}$ & 50 BRCAm $(100 \%)$ & 20 PlatS $(40 \%)$ & $400 \mathrm{mg}$ bid & $\begin{array}{l}26 \%(16-38) \\
\text { PlatS: } 35 \%(18-56) \\
\text { PlatR: } 20 \%(9-36)\end{array}$ \\
\hline \multirow[b]{2}{*}{$\begin{array}{l}\text { Steffensen et al. [132] } \\
\text { (NCT01472783) }\end{array}$} & \multirow[b]{2}{*}{ Phase 1-2 } & \multirow[b]{2}{*}{48} & \multirow[b]{2}{*}{ Median 4} & \multirow[b]{2}{*}{48 BRCAm $(100 \%)$} & \multirow{2}{*}{$\begin{array}{l}13 \text { Plat S (with PFI } \\
6-12 \mathrm{~m}) \\
\text { Phase I: } 4(12.5 \%) \\
\text { Phase II: } 9(28.1 \%)\end{array}$} & Phase I: escalation from $300 \mathrm{mg}$ bid & Phase I: NR \\
\hline & & & & & & Phase II: $300 \mathrm{mg}$ bid & $\begin{array}{l}\text { Phase II: } 44 \% \\
\text { Plat S: } 50 \% \\
\text { Plat R: } 41 \%\end{array}$ \\
\hline \multicolumn{8}{|c|}{ TALAZOPARIB } \\
\hline \multirow[t]{2}{*}{$\begin{array}{l}\text { De Bono et al. [133] } \\
\text { (NCT01286987) }\end{array}$} & \multirow[t]{2}{*}{ Phase 1} & \multirow[t]{2}{*}{$\begin{array}{l}34 \\
\text { Part 1: } 23 \\
\text { Part 2: } 11 \text { BRCAm }\end{array}$} & \multirow[t]{2}{*}{$\begin{array}{l}\text { Overall median: } 2.5 \\
\text { Part 1 median: } 4 \\
\text { Part 2: median } 2\end{array}$} & \multirow[t]{2}{*}{$\begin{array}{l}\text { Part 1: NR } \\
\text { Part 2: } 11(100 \%)\end{array}$} & \multirow[t]{2}{*}{ NR } & \multirow[t]{2}{*}{$\begin{array}{l}\text { Part 1: escalation } 0.025-1.1 \mathrm{mg} \mathrm{qd} \\
\text { Part 2: expansion. } 1 \mathrm{mg} \text { qd. }\end{array}$} & $\begin{array}{l}\text { Both cohorts: } \\
\text { BRCAm: } 48 \% \text {. } \\
\text { PlatS: } 55 \% \\
\text { Plat R: } 20 \% \\
\end{array}$ \\
\hline & & & & & & & Part 2: $41.7 \%$ \\
\hline
\end{tabular}


Maintenance Treatment

PARPi have been assessed as maintenance treatment in frontline and in platinum sensitive recurrence (Table 2), following response to platinum chemotherapy.

First Line

The phase III SOLO1 (NCT01844986) trial assessed olaparib/placebo maintenance treatment in stage III and IV OC with germline or somatic BRCAm, following response to first-line platinum-based chemotherapy [139]. The sBRCAm population in this study was underrepresented (two centrally confirmed sBRCAm of the 391 patients). The risk of disease progression at three years was significantly lower in the olaparib arm $(60 \%$ vs. $27 \%$; HR $0.3, p<0.001)$ (Figure 2). Time from randomisation to progression on second line of treatment (PFS2) at three years was superior in the olaparib arm (HR 0.5, $p<0.001)$. Overall survival data continues to be immature but no significant differences have been found so far (Table 2). Other studies assessing frontline maintenance PARPi treatment non-restricted to BRCAm carriers are ongoing (PRIMA, NCT02655016).

\section{Progression-free Survival as Assessed by Investigators}

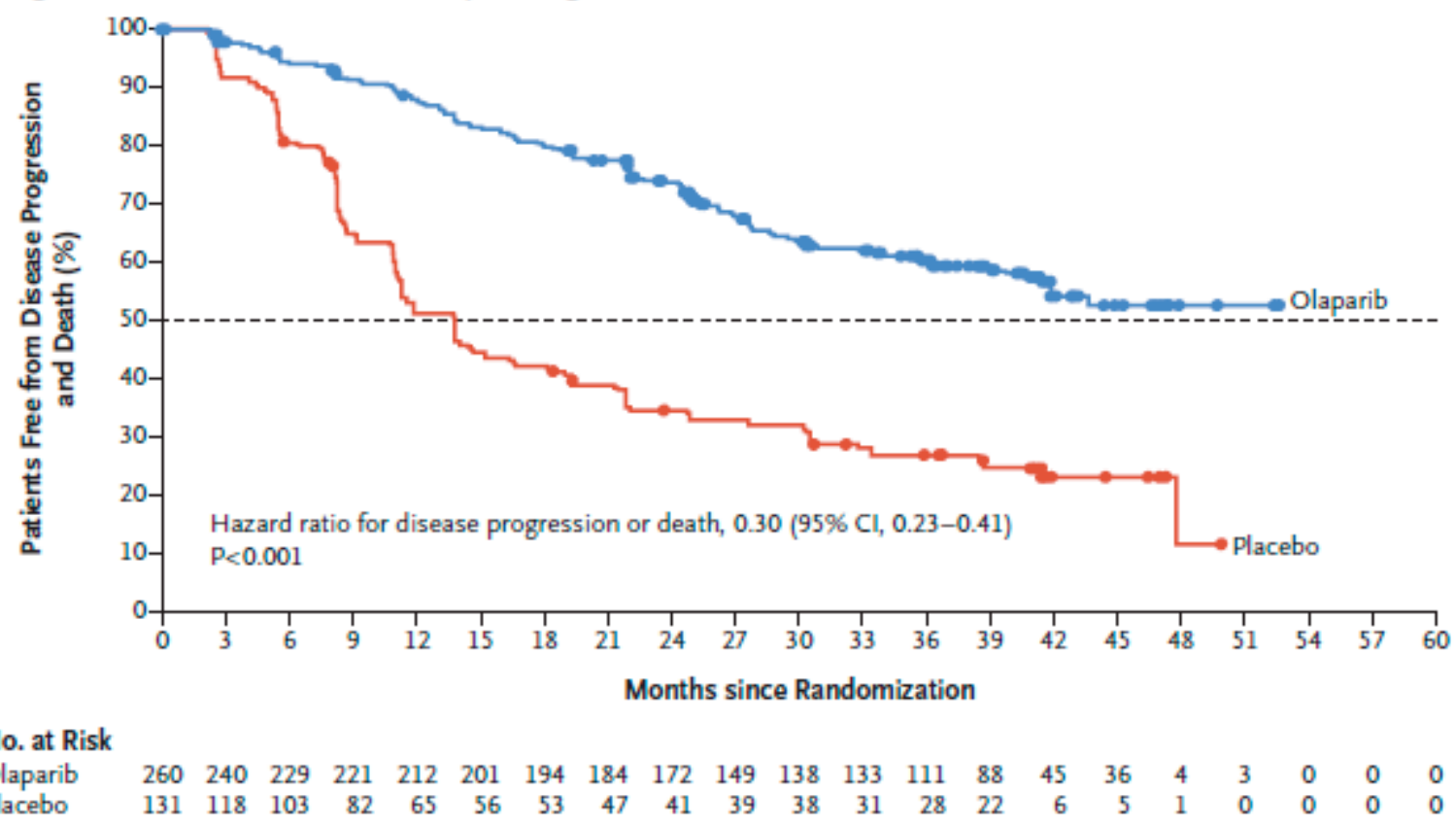

Figure 2. Kaplan-Meier estimates of the rate of freedom from disease progression, as assessed by investigators, and from death in the olaparib group and the placebo group of SOLO1 clinical trial. 
Table 2. Randomized double-blind phase II and III trials assessing maintenance PARPi, showing PFS benefit, irrespective of BRCAm status, and non-significant or immature OS data. HRD: Homologous recombination deficiency. Non-HRD: Non homologous recombination deficient. HRDu: Homologous recombination deficiency unkown. LOHh: High loss of heterozygocity, LOHl: Low loss of heterozygocity; LOHu: Unkown loss of heterozygocity. NA: Not applicable. NR: Not reported.

\begin{tabular}{|c|c|c|c|c|c|c|c|c|}
\hline & Trial Design & Patient Characteristics & $B R C A / H R D$ & PFS & PFS (BRCAm) & $\begin{array}{c}\text { PFS } \\
\text { (BRCAwt/HRD) }\end{array}$ & $\begin{array}{c}\text { PFS } \\
\text { (BRCAwt/non-HRD) }\end{array}$ & os \\
\hline \multicolumn{9}{|c|}{ OLAPARIB-FRONT LINE } \\
\hline $\begin{array}{l}\text { Moore et al. [139] } \\
\text { SOLO1 (NCT01844986) }\end{array}$ & $\begin{array}{l}\text { Phase III. } \\
\text { Olaparib vs. } \\
\text { placebo. }\end{array}$ & $\begin{array}{l}\text { N: } 391 \\
\text { Serous 96\% } \\
\text { Front line. }\end{array}$ & $\mathrm{g} B R C A \mathrm{~m} 99 \%$ & $\begin{array}{l}\text { At } 3 \text { years: } 60 \% \text { vs. } 27 \% \\
\text { HR } 0.3, p<0.001\end{array}$ & (Same as overall population) & NA & NA & $\begin{array}{l}\text { Immature } \\
\text { HR } 0.95 \text { (95\% CI 0.6-1.53) }\end{array}$ \\
\hline \multicolumn{9}{|c|}{ OLAPARIB-PLATINUM SENSTIVE RECURRENCE } \\
\hline $\begin{array}{l}\text { Ledermann et al. } \\
\text { [140-142] STUDY19 } \\
\text { (NCT00753545) }\end{array}$ & $\begin{array}{l}\text { Phase II. } \\
\text { Olaparib vs. } \\
\text { placebo. }\end{array}$ & $\begin{array}{l}\text { N: } 265 \\
\text { High grade serous } 91 \% \\
\leq 2 \text { prior platinum } 58 \%\end{array}$ & $\mathrm{~g} / \mathrm{sBRCAm} 51 \%$ & $\begin{array}{l}8.4 \text { vs. } 4.8 \text { months HR } \\
0.35, p<0.001 .\end{array}$ & $\begin{array}{l}11.2 \text { vs. } 4.3 \text { months } \\
\text { HR0.18, } p<0.0001\end{array}$ & NA & $\begin{array}{l}7.4 \text { vs. } 5.5 \text { months } \\
\text { HR } 0.54, p=0.0075\end{array}$ & $\begin{array}{l}29.8 \text { vs. } 27.8 \text { months } \\
\text { HR0.73, } p=0.025, \text { NS. }\end{array}$ \\
\hline $\begin{array}{l}\text { Pujade-Lauraine et al. } \\
\text { [143] } \\
\text { SOLO2/ENGOT-OV21 } \\
\text { (NCT01874353) }\end{array}$ & $\begin{array}{l}\text { Phase III. } \\
\text { Olaparib vs. } \\
\text { placebo. }\end{array}$ & $\begin{array}{l}\text { N: } 295 \\
\text { Serous } 91 \% \\
\leq 2 \text { prior platinum } 58 \%\end{array}$ & $\mathrm{gBRCAm} \mathrm{97 \%}$ & $\begin{array}{l}19.1 \text { vs. } 5.5 \text { months } \\
\text { HR } 0.3, p<0.0001 \text {. }\end{array}$ & (Same as overall population) & NA & NA & $\begin{array}{l}\text { Immature. } \\
\text { HR: } 0.8, p=0.43\end{array}$ \\
\hline \multicolumn{9}{|c|}{ NIRAPARIB-PLATINUM SENSTIVE RECURRENCE } \\
\hline $\begin{array}{l}\text { Mirza et al. [144] } \\
\text { ENGOT-OV16/NOVA } \\
\text { (NCT01847274) }\end{array}$ & $\begin{array}{l}\text { Phase III. } \\
\text { Niraparib vs. } \\
\text { placebo. }\end{array}$ & $\begin{array}{l}\text { N: } 553 \\
\text { Predominantly high grade serous. } \\
\leq 2 \text { prior chemotherapy } 60 \%\end{array}$ & $\begin{array}{l}\text { gBRCAm: } 203(37 \%) \\
\text { gBRCAwt:350 (63\%) } \\
\text { HRD: } 162 \\
\text { Non-HRD: } 134 \\
\text { HRDu: } 54\end{array}$ & NR & $\begin{array}{l}21 \text { vs. } 5.5 \text { months } \\
\text { HR0.27, } p<0.001 .\end{array}$ & $\begin{array}{l}12.9 \text { vs. } 3.8 \text { months } \\
\text { HR0.38, } p<0.001\end{array}$ & $\begin{array}{l}6.9 \text { vs. } 3.8 \text { months } \\
\text { HR 0.58. } p=0.02 .\end{array}$ & NR \\
\hline \multicolumn{9}{|c|}{ RUCAPARIB-PLATINUM SENSTIVE RECURRENCE } \\
\hline $\begin{array}{l}\text { Coleman et al. [145] } \\
\text { ARIEL } 3 \\
\text { (NCT01968213) }\end{array}$ & $\begin{array}{l}\text { Phase III. } \\
\text { Rucaparib vs. } \\
\text { placebo. }\end{array}$ & $\begin{array}{l}\text { N: } 564 \\
\text { Serous } 95 \% \\
\leq 2 \text { prior chemotherapy } 63 \%\end{array}$ & $\begin{array}{l}\text { g/sBRCAm 196 (35\%) } \\
\text { LOHh } 158(28 \%) \\
\text { LOHl } 161(29 \%) \\
\text { LOHu } 49(9 \%)\end{array}$ & $\begin{array}{l}10.8 \text { vs. } 5.4 \text { months } \\
\text { HR } 0.36, p<0.0001\end{array}$ & $\begin{array}{l}16 \text { vs. } 5.4 \text { months } \\
\text { HR0. } 23, p<0.0001\end{array}$ & $\begin{array}{l}9.7 \text { vs. } 5.4 \text { months } \\
\text { HR0.44, } p<0.0001\end{array}$ & $\begin{array}{l}6.7 \text { vs. } 5.4 \text { months } \\
\text { HR } 0.58, p=0.0049\end{array}$ & NR \\
\hline
\end{tabular}




\section{Platinum Sensitive Relapse}

Results of Study19 (NCT00753545) lead to the approval of olaparib as the first PARPi as maintenance treatment for $B R C A m$ OC by the European Medicine Agency (EMA). It was subsequently approved in the maintenance setting by the FDA and Health Canada.

Study19 was a phase II placebo-controlled trial of platinum sensitive OC treated with at least two prior lines of platinum-based chemotherapy and response to the last treatment. There was a significantly longer PFS in the olaparib arm (8.4 vs. 4.8 months; HR $0.35, p<0.001)$ [140]. A preplanned retrospective analysis of the data by $B R C A \mathrm{~m}$ status identified $51 \%$ of patients harbored a germline or somatic $B R C A \mathrm{~m}$, being associated with a significant PFS increase in the olaparib group (11.2 vs. 4.3 months; HR $0.18, p<0.0001) ; B R C A$ wt women also had PFS improvement; however, the difference between the groups was lower (7.4 vs. 5.5 months; HR 0.54, $p=0.0075$ ). Somatic BRCAm were found in $14 \%$ of women, having fewer progression events when treated with olaparib (38\% vs. $60 \%$ ) [141]. Although the study was not powered to assess OS, no statistically significant differences were found (HR 0.73, 95\% CI 0.55-0.96; $p=0.025$, required threshold $p<0.0095$ ). [142].

SOLO2/ENGOT-Ov21 (NCT01874353) phase III randomised trial assessing olaparib/placebo as maintenance treatment in platinum sensitive OC with $\mathrm{gBRCAm}$ (sBRCAm not included), showed that the investigator-assessed PFS was significantly longer in the olaparib arm (19.1 vs. 5.5 months; HR 0.3, $p<0.0001$ ). OS data was still immature (HR 0.8, $p=0.43$ ) [143].

Rucaparib and niraparib have been also assessed as maintenance treatments in randomised double-blind phase III trials, but the population included in these studies was not limited to those carrying BRCAm. The ENGOT-OV16/NOVA (NCT01847274) trial, assessing niraparib maintenance, included two independent cohorts, $\mathrm{g} B R C A \mathrm{~m}$ and non-gBRCA. Tumour testing was performed on archival tissue to define HRD; 553 patients were enrolled, of whom $37 \%$ harbored gBRCAm. PFS was significantly longer in the niraparib arm in all pre-specified cohorts, gBRCAm (21 vs. 5.5 months; HR $0.27, p<0.001)$, non-gBRCAm with HRD (12.9 vs. 3.8 months; HR 0.38, $p<0.001$ ), and BRCAwt subgroup (9.3 vs. 3.9 months; HR0.45, $p<0.001$ ). Those with $s B R C A m$ had a similar reduction in the risk of progression than $\mathrm{g} B R C A \mathrm{~m}$. Niraparib also showed PFS improvement in the HRD-negative exploratory subgroup (6.9 m vs. $3.8 \mathrm{~m}$; HR 0.58, $p=0.02)$ [144].

The randomised phase III trial, ARIEL3 (NCT01968213), assessing rucaparib maintenance therapy following completion of platinum-based chemotherapy for platinum sensitive recurrence used the same LOH assay as described in ARIEL2 part1, with a modified cut off point refined from Ariel 2 , to validate $B R C A \mathrm{~m}$ and $\mathrm{LOH}$ as potential biomarkers. Rucaparib maintenance improved PFS in all pre-specified subgroups, germline and somatic BRCAm carriers (16.6 vs. 5.4 months; HR 0.23, $p<0.0001$ ), HRD tumours, including BRCAm and LOH-high (13.6 vs. 5.4 months, HR $0.32, p<0.0001$ ), and in the intention-to-treat population (10.8 vs. 5.4 months, HR $0.36, p<0.0001)$. Interestingly, in the exploratory non-HRD subgroup rucaparib also demonstrated benefit (HR 0.58, $p=0.0049)$ [145].

There are several notable differences in the three PARPi maintenance phase III trials described above, which may influence data interpretation. Regarding the clinical parameters, NOVA trial was restricted to patients with residual disease $<2 \mathrm{~cm}$, while the other trials did not have disease size restriction. The inclusion criteria for Cancer antigen 125 (CA-125) levels was also different in the three trials; whereas ARIEL3 was restricted to those with a normal level, NOVA included those with a decrease greater than $90 \%$ in the last platinum-based regimen, and SOLO2 was less restrictive allowing all patients without an evidence of rising CA-125. SOLO2 only enrolled women with a gBRCAm, while the trials assessing niraparib and rucaparib also enrolled patients without $B R C A m$. In addition, the subgroup classification was different, $\mathrm{s} B R C A \mathrm{~m}$ patients were analysed as part of the HRD subgroup in NOVA, whereas in ARIEL3, sBRCAm patients were part of the BRCAm subgroup. Different assays were used in order to define the HRD subgroup; NOVA applied the Myriad mychoice HRD test and ARIEL3 the Foundation medicine T5 NGStool [143-145]. Toxicity data along the different PARPi are summarized in Table 3. 
Table 3. Toxicity data from SOLO2, NOVA, ARIEL3 and FDA, EMA reports [143-147]. Cap: capsule, Tab: Tablet, GI: Gatrointestinal, ALT: Alanine aminotransferase, AST: aspartase aminotransferase, BID: twice daily, QD: once daily, Ch: chemotherapy.

\begin{tabular}{|c|c|c|c|}
\hline & Olaparib & Niraparib & Rucaparib \\
\hline Dosage & $\begin{array}{l}\text { Cap: } 400 \mathrm{mg} \text { bid } \\
\text { Tab: } 300 \mathrm{mg} \text { bid }\end{array}$ & $300 \mathrm{mg}$ qd & $600 \mathrm{mg}$ bid \\
\hline FDA Approval & $\begin{array}{l}\text {-2014: Single agent treatment. Cap formulation. } \\
\text { gBRCAm, } \geq 3 \text { prior Ch lines. } \\
\text {-2017: Maintenance treatment. PlatS, and response } \\
\text { to platinum Ch. Regardless of } B R C A m \text { status. } \\
\text {-2018: First-line maintenance. Germline or somatic } \\
\text { BRCAm carriers. }\end{array}$ & $\begin{array}{l}\text {-2017: Maintenance treatment. PlatS relapse, } \\
\text { and response to platinum Ch. Regardless of } \\
\text { BRCAm status. }\end{array}$ & $\begin{array}{l}\text {-2018: Maintenance treatment. PlatS, } \\
\text { and response to platinum Ch. Regardless of } \\
B R C A m \text { status. }\end{array}$ \\
\hline EMA Approval & $\begin{array}{l}\text {-2014: Maintenance treatment. Cap formulation. } \\
\text { g/sBRCAm, PlatS relapse, and response to platinum. } \\
\text {-2018: Maintenance treatment. Tablet formulation. } \\
\text { PlatS relapse, and response to platinum Ch. } \\
\text { Regardless of BRCAm status. }\end{array}$ & $\begin{array}{l}\text {-2017: Maintenance treatment. PlatS relapse, } \\
\text { and response to platinum Ch. } \\
\text { Regardless BRCAm status. }\end{array}$ & $\begin{array}{l}\text {-2018: Maintenance treatment. Germline or } \\
\text { somatic BRCAm, PlatS and response to } \\
\text { platinum Ch. }\end{array}$ \\
\hline \multicolumn{4}{|l|}{ Toxicity } \\
\hline Drug class toxicity & $\begin{array}{l}\text { GI, fatigue, myelosuppression, headache, decrease } \\
\text { appetite, creatinine increase, dyspnea. }\end{array}$ & $\begin{array}{l}\text { GI, fatigue, myelosuppression, headache, } \\
\text { decrease appetite, creatinine increase, dyspnea. }\end{array}$ & $\begin{array}{l}\text { GI, fatigue, myelosuppression, headache, } \\
\text { decrease appetite, creatinine increase, dyspnea. }\end{array}$ \\
\hline$\geq 10 \%$, grade $\geq 3$ & Anemia. & Anemia, neutropenia, Thrombocytopenia. & Anemia, $\uparrow$ ALT/AST. \\
\hline Drug specific & - & Hypertension & $\uparrow \mathrm{ALT} / \mathrm{AST}$ \\
\hline Other & Overall risk of MDS/AML 1\%. & & \\
\hline
\end{tabular}


Although a longer PFS was reported for PARPi maintenance in women with BRCAm and HRD, the assays were unable to accurately predict who would not benefit from PARPi in NOVA, ARIEL3 and STUDY19 trials. These studies have also shown improvement in time to second subsequent treatment/ PFS2; however, OS data are still immature [140-145]. PARPi treatment is also associated to high drug acquisition cost [148]. Some women on PARPi have durable long-term control of disease, in some cases approaching 10 years. Learning from these long term PARPi responders may provide valuable information and improve our understanding of the associated mechanisms of action and define predictive biomarkers [140,149-151]. A study on long term responders with $>2$ years of olaparib response is ongoing (OLALA, NCT02489058).

\section{Combination Treatments}

Several PARPi have been assessed in combination with chemotherapy, anti-angiogenics, immunotherapy or targeted treatments. Contemporary combination trials have not been restricted to $B R C A m$ population.

The combination of chemotherapy and PARPi was assessed in STUDY41 (NCT01081951), a randomised phase II trial where patients with platinum sensitive recurrence received either olaparib in combination with carboplatin and paclitaxel followed by maintenance olaparib, or carboplatin and paclitaxel alone. Women receiving olaparib had an improvement in PFS (12.2 vs. 9.6 months; HR 0.51, $p=0.012$ ), with a greater benefit seen in BRCAm patients (HR 0.21, $p=0.0015$ ). Although the study was not designed to measure the contribution of each treatment, the late separation of the PFS curves suggested that the maintenance phase was the key contributor to the improvement [149].

The combination of PARPi with PLD has also been explored in a phase I dose-finding trial with 44 patients, using continuous or intermittent schedule. In this trial, $28 \mathrm{OC}$ patients were included, from which $11 \mathrm{gBRCAm}$, with an ORR 50\% and 61\% respectively [152]. The maximum tolerated dose was not reached using continuous olaparib $400 \mathrm{mg}$ twice daily and PLD $\left(40 \mathrm{mg} / \mathrm{m}^{2}\right)$. Currently a single arm phase II trial is ongoing in platinum resistant OC irrespective of the BRCAm status, assessing the combination of PLD $40 \mathrm{mg} / \mathrm{m}^{2}$ every 28 days and olaparib $300 \mathrm{mg}$ twice daily (NCT03161132).

Antiangiogenic treatment has also been explored in combination with PARPi. Preclinical studies have shown a synergy between the two pathways. In fact, antiangiogenics can induce tumour hypoxia, leading to downregulation of $B R C A$ and $R A D 51$, and possibly increasing tumour sensitivity to chemotherapy and PARPi [153-155]. Preclinical data demonstrated that hypoxia-mediated defects in DNA repair can lead to genetic instability and drive oncogenesis [156]. In a randomised phase II study olaparib was compared to the combination of olaparib and cediranib, a vascular endothelial growing factor (VEGF) receptor and c-kit tyrosine kinases inhibitor, in patients with platinum sensitive HGSOC, endometrioid or gBRCAm OC. There was a PFS (17.7 vs. $9 \mathrm{~m}, \mathrm{HR} 0.42, p=0.005)$ and ORR benefit ( $56 \%$ vs. $84 \%, p=0.008)$ in the combination arm. Interestingly, in subgroup analysis the benefit was only significant in $\mathrm{g} B R C A$ wt or unknown status (HR $0.32, p=0.008$ ), with a trend in $\mathrm{g} B R C A \mathrm{~m}$ subgroup (HR 0.55, $p=0.16$ ). Although the study was not powered to detect OS differences, updated results have found a trend towards OS improvement in BRCAwt (HR 0.48, $p=0.074$ ). Drug-related adverse events (AEs) were more common in the combination arm, with $70 \%$ experiencing grade 3 or higher events $[157,158]$. A non-randomised phase II study with olaparib and cediranib combination in the cohort of platinum sensitive and resistant populations showed an ORR of $77 \%$ and $20 \%$, respectively. Responses were seen in platinum resistant BRCAwt women, but benefit was higher in those with gBRCAm. [159]. In platinum sensitive population, the OVC1 (NCT02446600) phase III trial assessed olaparib vs. olaparib and cediranib vs. platinum-based chemotherapy; results are awaited. Similarly, OVC2 (NCT02502266) is a randomised trial assessing the combination in platinum resistant setting and currently ongoing. Other combinations with bevacizumab, an anti-VEGF monoclonal antibody, are also being assessed (PAOLA1, NCT02477644; AVANOVA, NCT02354131; OVARIO, NCT0332619). 
PARPi have been found to induce PI3K pathway activity in preclinical models, whereas PI3K suppression induces DNA damage [160-162]. Combination of a PI3K inhibitor with PARPi has shown synergy in BRCA1m and BRCAwt breast cancer xenografts [161]. A phase I trial assessing BKM120, a PI3K inhibitor, and olaparib included 46 OC patients, showing an ORR of $29 \%$ (90\% CI: $18-43 \%$ ) irrespective of platinum-sensitivity. Dose limiting toxicities included grade 3 transaminase elevation and depression [163]. Similarly, a phase I trial combining olaparib and vistusertib, a mTORC1/2 inhibitor, has shown an ORR of $20 \%$ in the OC subgroup, where most of the patients were platinum resistant [164]. The combination of olaparib and AZD5363, AKT inhibitor, has also been assessed in a phase I multitumour study, showing an ORR of $24 \%$ [165]. Further studies are needed on this combination for BRCAm and wild-type patients.

The best treatment option at the time of PARPi progression remains unclear; although, retrospective data suggests that there is no significant clinical cross-resistance between PARPi and platinum-based chemotherapy and platinum continues to be the treatment of choice [166]. Whether retreatment with PARPi or new combinations are beneficial, especially in those harbouring BRCAm or HRD, is under investigation (NCT03106987, NCT02340611).

\subsubsection{Antiangiogenic Treatment}

Angiogenesis is one of the hallmarks in OC pathogenesis. VEGF and angiogenesis promote tumour growth and progression, as well as ascites formation, and vascular density is a negative prognostic marker [167-170]. Anti-angiogenic agents are part of the OC treatment in frontline as well as in the relapsed setting, regardless of BRCAm status. HRD or BRCAm status has not been found to be a response biomarker $[171,172]$ for antiangiogenics.

In the frontline setting, addition of bevacizumab to carboplatin and paclitaxel, followed by maintenance bevacizumab has shown a PFS benefit in ICON7 (NCT00483782) (for an additional 12 cycles at $7.5 \mathrm{mg} / \mathrm{kg}$; HR $0.81 p=0.004$ ) and GOG-218 (NCT00262847) (for a total of 22 cycles at $15 \mathrm{mg} / \mathrm{kg}$; HR $0.7 \mathrm{P}<0.001)$ randomised phase III studies. No OS benefit was found in the intention-to-treat population $[173,174]$. However, high-risk subgroup in an exploratory analysis of ICON7 (suboptimally debulked stage III/IV, non-operated patients) had a significant OS improvement (HR $0.78 p=0.03$ ) [175]. The benefit of anti-angiogenic agents frontline was further assessed with pazopanib, showing PFS (17.9 vs. 12.3 months; HR $0.77, p=0.0021)$ but no OS benefit. Toxicity was challenging, with $33.3 \%$ treatment discontinuations [176]. gBRCAm status has been assessed retrospectively and is not a predictive biomarker for antiangiogenic combination therapy [172].

\subsubsection{Immunotherapy}

Preclinical data has shown that intact immune surveillance is needed to control tumour transformation and growth [177]. In fact, restoring anti-cancer immunity by immune checkpoint blockade has been successful in several tumours. The activation of immune response requires the recognition of the cancer antigen by $\mathrm{T}$ cell receptors (TCR), as well as several co-stimulatory and inhibitory signals $[178,179]$. PD1 and its receptor PD-L1 play an important role in the interaction of tumour cells and tumour-specific T cells [180]; antibodies against these immune checkpoints can activate the anti-tumour response.

HGSOC has a relatively low tumour mutational burden (TMB) and immunogenicity, with low PDL1 expression in late progressing tumours [181]. However, cancer cells with genomic instability and deficiency in DNA repair, such as microsatellite unstable or POLE mutated tumours have a higher TMB, source of neoantigens, and thus an increased response to immune checkpoint inhibitors [182,183]. Similarly, germline and somatic BRCAm HGSOC have a higher TMB, as well as increased immune infiltrates, which are not seen in HR proficient HGSOC $[184,185]$. Tumour-infiltrating $\mathrm{T}$ cells are also increased in BRCA1m OC [186]. Thus, BRCAm HGSOC might have an immunogenic phenotype, and be a potential biomarker for treatment with immunotherapy [181]. 
Several antibodies against PD-1, PD-L1, CTLA4 have been tested in OC patients, most of them without any selection biomarker. Multi-tumour or small early phase trials have shown modest activity of single agent immunotherapy with ORR that ranges between $6 \%$ and $11.5 \%$ [187-190]. KEYNOTE-100 study (NCT02674061), a phase II single-arm trial assessing pembrolizumab in recurrent OC included two cohorts: cohort A with up to three lines of treatment, and cohort B with 4-6 prior lines of treatment. The study showed a modest anti-tumour effect, with ORR of $8 \%, 7.4 \%$ and $9.9 \%$, for all patients, cohort $\mathrm{A}$ and $\mathrm{B}$, respectively. Response according to histological subtypes or BRCAm status has not been reported [191]. Other immunotherapy agents such as indoleamine 2,3-dioxygenase-1 (IDO1) inhibitor and CA125 targeting vaccines have shown no significant efficacy in OC $[192,193]$.

Given the modest results of single agent immunotherapy, there is an effort to find combinations that could overcome resistance to checkpoint inhibitors and increase immunogenicity of OC. Several on-going trials are combining checkpoint inhibitors with chemotherapy, PARPi or vaccines (NCT03330405, NCT03029403).

Preclinical models indicate synergy between PARPi and checkpoint inhibitors, regardless of BRCAm or PDL1 status [194-196]. A phase I-II trial, TOPACIO (NCT02657889), on recurrent OC (platinum sensitive 17\%; BRCAwt 77\%) assessing the combination of niraparib and pembrolizumab, has shown an ORR of $25 \%$, with duration of response of 9.3 months. In platinum resistant patients, the efficacy was found to be similar regardless of BRCAm and HRD [197]. MEDIOLA (NCT02734004) assessing the combination of olaparib and durvalumab showed an ORR of $63 \%$ in the gBRCAm platinum sensitive OC cohort [198].

Combination trials are ongoing in frontline and recurrent setting, where immune checkpoint inhibitors are combined with chemotherapy, antiangiogenics and PARPi.

\subsubsection{Other Agents Under Investigation}

Cell Cycle Modulators

Cell cycle checkpoints are essential for DNA repair and maintenance of genomic integrity. WEE-1 kinase is a G2 cell-cycle checkpoint regulator that is activated in response to DNA damage. Thus, WEE-1 inhibitors can abrogate G2 cell cycle arrest. Loss of cell cycle dependent genes and replication stress are being studied as biomarkers of response to this treatment [199]. Most HGSOC are TP53 deficient, having a defective G1 checkpoint [200]. Tumour cells with deficient G1 checkpoint, treated with a WEE-1 inhibitor lose the ability to arrest the cell cycle in response to DNA damage, and enhance apoptosis. Preclinical data have shown potential effectiveness of the treatment in OC xenografts, irrespective of TP53 status and BRCA1m [201]. However, a phase I dose-finding multi-tumour study did suggest that $B R C A \mathrm{~m}$ and HRD might be response biomarkers to WEE1 kinase inhibitor monotherapy [202]. Indeed, CDK1, the main target of WEE1, plays a key role in HR and dsDNA break repair [203]. In vitro studies have shown synergy between CDK1 inhibition and PARPi, a combination that is being further investigated [204,205].

A phase II proof-of-concept trial was conducted assessing the combination of WEE-1 inhibitor, AZD1775, as an enhancer of carboplatin on TP53 mutated platinum resistant (PFI $\leq 3 \mathrm{~m}$ ) OC upon first recurrence. An ORR of $43 \%$ was found, suggesting a possible synergy. There were two prolonged response patients, one of them harbored a BRCA1, MYC and CCNE1 alterations [206].

Prexasertib, a checkpoint kinase 1 and 2 inhibitor, has been assessed in a proof-of-concept phase II study in recurrent HGSOC, showing an ORR of $29 \%$ in non-gBRCAm carriers, results awaited for the $\mathrm{gBRCAm}$ cohort [207].

\section{BRCA Mutations and Treatment Resistance}

The impact of $B R C A \mathrm{~m}$ on treatment response might be variable, as $B R C A \mathrm{~m}$ in the tumour might evolve over time as resistance develops. Secondary point mutations that are actionable are rare in relapsed chemotherapy resistant HGSOC [208]. Several mechanisms of resistance to PARPi and platinum have been 
reported, including increased HR capacity with $B R C A$ reversions mutations, non-homologous end-joint (NHEJ) repair alterations, reduction in PARP1 activity and cell stromal alterations, such as changes in cellular adhesion molecules [208]. Mutations in the RING-type zinc finger (RING) domain of BRCA1 have also shown to be predictive of poor response to platinum and PARPi [209].

\subsection{Increased HR Activity}

Secondary BRCAm that restore BRCA1/2 function are the most studied mechanism of drug resistance to platinum and PARPi [208,210,211]. However, the mechanism of acquiring drug resistance is still under investigation. DNA damaging agents or BRCA1/2 deficiency itself exhorts selective pressure, leading to adoptive changes and increased mutational rate. Tumours are heterogeneous and clonal selection after treatment with DNA damaging agents (Figure 3) may select for resistance [212].

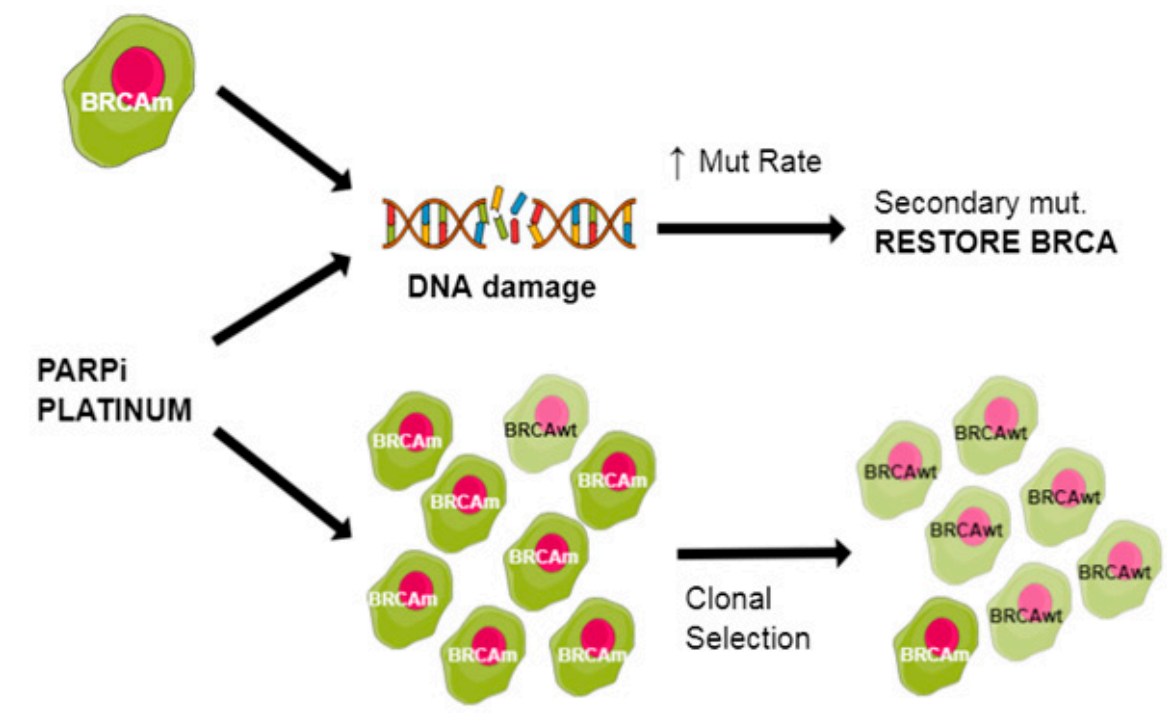

Figure 3. Potential mechanisms to restore BRCA function.

Tumour heterogeneity has been found across different studies. Patch et al. performed germline and somatic whole genome sequencing in 92 OC and matched with acquired resistant disease. In five cases reversion mutations were found, out of which two cases contained multiple mutations. An autopsy revealed 12 different reversion $B R C A 2 \mathrm{~m}$ [208]. Similarly, 12 patients with tissue post-progression on rucaparib from ARIEL2 study found BRCA1, RAD51C and RAD51D mutations in six patients, and in five of them one or more secondary mutation restoring the reading frame were seen [213]. Complementary in vitro assays and patient derived xenografts confirmed that resistance to rucaparib was associated with the secondary mutations. Loss of BRCA1 promoter methylation was also reported as a mechanism to restore BRCA1 function [213]. In addition, methylation of all BRCA1 copies was found to be a predictor of response to rucaparib using patient derived xenografts, while heterozygous methylation was associated with resistance [214].

\subsection{Non-Homologous End Joining (NHEJ) Factors and Shieldin Complex}

In addition to HR, DSB can be repaired by NHEJ through direct joining across the break sites; although, data suggests that HRD cells with disabling NHEJ reverses genomic instability induced by PARPi and rescues from lethality of PARPi [215].

In BRCA1 deficient cell DNA breaks are aberrantly joined by NEHJ factors, such as 53BP1 and Ligase 4. Interestingly, in BRCA1 (but not BRCA2) deficient cells, the loss of 53BP1 rescues Rad51-dependent HR, partially blocking ATM resection [216-218]. Thus, in the absence of both 53BP1 and BRCA1, proteins involved in HR are loaded normally at the chromosomal break site, permitting error-free DNA repair. In fact, BRCA1/53BP1 double-deficient cells are resistant to PARPi, and combination of both have been 
suggested as predictive biomarkers of sensitivity [216-218]. Decreased 53BP1 expression has not been found to correlate with platinum resistance [219].

Shieldin complex is involved in dsDNA break localization, and its loss impairs NHEJ. Mutations in genes related to shieldin complex can cause PARPi resistance in BRCA1 deficient tumours [220,221].

\subsection{Drug Efflux Pump}

Overexpression of drug efflux transporters, particularly ATP-binding cassette membrane transporters, represents an additional mechanism of acquired drug resistance. The $A B C B 1$ gene encodes the multidrug-resistant protein 1 (MDR1), which is associated with a rapid efflux of many chemotherapeutic agents including paclitaxel, etoposide and doxorubicin. Patch et al. found overexpression of MDR1 activity in $8 \%$ of recurrent HGSOC samples analyzed; the biological mechanism involved promoter fusion and translocation enabling overexpression [208]. Evidence suggests that drug efflux pumps might also be involved in PARPi resistance, and clinical trials are being planned to address this mechanism of resistance [222].

\subsection{Stromal Reactions}

From the autopsy of a chemo-resistant OC patient, Patch et al. described no reverse BRCAm and maintained HR, but an extensive desmoplatic stromal reaction in histological examination [208]. Stromal reactions are associated with poor drug uptake and have been found as chemoresistance mechanisms in other cancers [208,223].

\section{Conclusions}

The presence of germline and somatic $B R C A \mathrm{~m}$ confers distinct characteristics to $\mathrm{OC}$ and is now considered to be essential information to plan OC treatment. Assessment of gBRCAm is not only a tool for cancer prevention and family counselling, but also a predictive factor confining increased response to DNA damaging agents, such as platinum chemotherapy. PARPi have shown to be effective as single agent and as maintenance treatment, particularly in germline and somatic BRCAm carriers. This has led to a major emphasis on BRCAm testing. Germline testing was initially only recommended in patients with positive family history; it is now recommended for all HGSOC. Contemporary somatic testing also provides valuable information and impacts patient care. Therefore, $B R C A$ reflex tumour testing should be performed at the time of initial diagnosis.

Several trials are ongoing assessing the combination of chemotherapy, immunotherapy and targeted agents in order to overcome resistance. Germline and somatic BRCAm should be integrated into routine clinical care and considered as stratification factor in clinical trials given its predictive value. It is also important to understand better resistance mechanisms of $B R C A m$ OC, in order to develop more effective and less toxic treatments, maintaining quality of life while and striving to improve survival. Cost-effectiveness of both the new treatments and genetic testing needs to be taken into account when setting priorities in health care policies.

Funding: There is no external funding.

Acknowledgments: We thank Marsela Braunstein and Katherine Karakasis for their expertise and assistance on the development of the manuscript.

Conflicts of Interest: A.M. declares no conflict of interest. S.L. is part of the steering committee of DUO, principal investigator and co-principal investigator of different trials with PARP inhibitors in ovarian cancer. A.O. is part of the steering committee of trials with AstraZeneca, Tesaro, Clovis, (non-compensated) IMGN.

\section{References}

1. Noone, A.M.; Howlader, N.; Krapcho, M.; Miller, D.; Brest, A.; Yu, M.; Ruhl, J.; Tatalovich, Z.; Mariotto, A.; Lewis, D.R.; et al. SEER Cancer Statistics Review, 1975-2015; National Cancer Institute: Bethesda, MD, USA, 2015. Available online: https:/ / seer.cancer.gov/csr/1975_2015/ (accessed on 1 June 2019). 
2. Ferlay, J.; Soerjomataram, I.; Dikshit, R.; Eser, S.; Mathers, C.; Rebelo, M.; Parkin, D.M.; Forman, D.; Bray, F. Cancer incidence and mortality worldwide: Sources, methods and major patterns in GLOBOCAN 2012. Int. J. Cancer 2015, 136, E359-E386. [CrossRef]

3. Ramalingam, P. Morphologic, Immunophenotypic, and Molecular Features of Epithelial Ovarian Cancer. Oncology 2016, 30, 166-176. [PubMed]

4. Kurman, R.J.; Carcangiu, M.L.; Herrington, C.S. World Health Organisation Classification of Tumours of the Female Reproductive Organs; International Agency for Research on Cancer: Lyon, France, 2014.

5. Torre, L.A.; Trabert, B.; DeSantis, C.E.; Miller, K.D.; Samimi, G.; Runowicz, C.D.; Gaudet, M.M.; Jemal, A.; Siegel, R.L. Ovarian cancer statistics, 2018. CA A Cancer J. Clin. 2018. [CrossRef]

6. Friedlander, M.; Trimble, E.; Tinker, A.; Alberts, D.; Avall-Lundqvist, E.; Brady, M.; Harter, P.; Pignata, S.; Pujade-Lauraine, E.; Sehouli, J.; et al. Clinical trials in recurrent ovarian cancer. Int. J. Gynecol. Cancer 2011, 21,771-775. [CrossRef] [PubMed]

7. Colombo, P.E.; Fabbro, M.; Theillet, C.; Bibeau, F.; Rouanet, P.; Ray-Coquard, I. Sensitivity and resistance to treatment in the primary management of epithelial ovarian cancer. Crit. Rev. Oncol./Hematol. 2014, 89, 207-216. [CrossRef] [PubMed]

8. Colombo, N.; Gore, M. Treatment of recurrent ovarian cancer relapsing 6-12 months post platinum-based chemotherapy. Crit. Rev. Oncol./Hematol. 2007, 64, 129-138. [CrossRef] [PubMed]

9. Wilson, M.K.; Pujade-Lauraine, E.; Aoki, D.; Mirza, M.R.; Lorusso, D.; Oza, A.M.; du Bois, A.; Vergote, I.; Reuss, A.; Bacon, M.; et al. Fifth Ovarian Cancer Consensus Conference of the Gynecologic Cancer InterGroup: Recurrent disease. Ann. Oncol. 2017, 28, 727-732. [PubMed]

10. Cancer Genome Atlas Research Network. Integrated genomic analyses of ovarian carcinoma. Nature 2011, 474, 609-615. [CrossRef]

11. Jones, S.; Wang, T.L.; Kurman, R.J.; Nakayama, K.; Velculescu, V.E.; Vogelstein, B.; Kinzler, K.W.; Papadopoulos, N.; Shih Ie, M. Low-grade serous carcinomas of the ovary contain very few point mutations. J. Pathol. 2012, 226, 413-420. [CrossRef] [PubMed]

12. Shanmughapriya, S.; Nachiappan, V.; Natarajaseenivasan, K. BRCA1 and BRCA2 mutations in the ovarian cancer population across race and ethnicity: Special reference to Asia. Oncology 2013, 84, 226-232. [CrossRef] [PubMed]

13. Struewing, J.P.; Hartge, P.; Wacholder, S.; Baker, S.M.; Berlin, M.; McAdams, M.; Timmerman, M.M.; Brody, L.C.; Tucker, M.A. The risk of cancer associated with specific mutations of BRCA1 and BRCA2 among Ashkenazi Jews. N. Engl. J. Med. 1997, 336, 1401-1408. [CrossRef]

14. Bayraktar, S.; Jackson, M.; Gutierrez-Barrera, A.M.; Liu, D.; Meric-Bernstam, F.; Brandt, A.; Woodson, A.; Litton, J.; Lu, K.H.; Valero, V.; et al. Genotype-Phenotype Correlations by Ethnicity and Mutation Location in BRCA Mutation Carriers. Breast J. 2015, 21, 260-267. [CrossRef] [PubMed]

15. Li, X.; Heyer, W.D. Homologous recombination in DNA repair and DNA damage tolerance. Cell Res. 2008, 18, 99-113. [CrossRef] [PubMed]

16. Welcsh, P.L.; King, M.C. BRCA1 and BRCA2 and the genetics of breast and ovarian cancer. Hum. Mol. Genet. 2001, 10, 705-713. [CrossRef] [PubMed]

17. Yoshida, K.; Miki, Y. Role of BRCA1 and BRCA2 as regulators of DNA repair, transcription, and cell cycle in response to DNA damage. Cancer Sci. 2004, 95, 866-871. [CrossRef]

18. Luo, G.; Lu, Y.; Jin, K.; Cheng, H.; Guo, M.; Liu, Z.; Long, J.; Liu, C.; Ni, Q.; Yu, X. Pancreatic cancer: BRCA mutation and personalized treatment. Expert Rev. Anticancer Ther. 2015, 15, 1223-1231. [CrossRef]

19. Taneja, S.S. Re: Germline Mutations in ATM and BRCA1/2 Distinguish Risk for Lethal and Indolent Prostate Cancer and are Associated with Early Age at Death. J. Urol. 2017, 198, 742-743. [CrossRef] [PubMed]

20. Friedenson, B. BRCA1 and BRCA2 pathways and the risk of cancers other than breast or ovarian. MedGenMed 2005, 7, 60. [PubMed]

21. Antoniou, A.; Pharoah, P.D.; Narod, S.; Risch, H.A.; Eyfjord, J.E.; Hopper, J.L.; Loman, N.; Olsson, H.; Johannsson, O.; Borg, A.; et al. Average risks of breast and ovarian cancer associated with BRCA1 or BRCA2 mutations detected in case Series unselected for family history: A combined analysis of 22 studies. Am. J. Hum. Genet. 2003, 72, 1117-1130. [CrossRef] 
22. Walsh, T.; Casadei, S.; Lee, M.K.; Pennil, C.C.; Nord, A.S.; Thornton, A.M.; Roeb, W.; Agnew, K.J.; Stray, S.M.; Wickramanayake, A.; et al. Mutations in 12 genes for inherited ovarian, fallopian tube, and peritoneal carcinoma identified by massively parallel sequencing. Proc. Natl. Acad. Sci. USA 2011, 108, 18032-18037. [CrossRef] [PubMed]

23. Norquist, B.M.; Harrell, M.I.; Brady, M.F.; Walsh, T.; Lee, M.K.; Gulsuner, S.; Bernards, S.S.; Casadei, S.; Yi, Q.; Burger, R.A.; et al. Inherited Mutations in Women With Ovarian Carcinoma. JAMA Oncol. 2016, 2, 482-490. [CrossRef]

24. Lynch, H.T.; Snyder, C.L.; Shaw, T.G.; Heinen, C.D.; Hitchins, M.P. Milestones of Lynch syndrome: 1895-2015. Nat. Rev. Cancer 2015, 15, 181-194. [CrossRef] [PubMed]

25. Aarnio, M.; Sankila, R.; Pukkala, E.; Salovaara, R.; Aaltonen, L.A.; de la Chapelle, A.; Peltomaki, P.; Mecklin, J.P.; Jarvinen, H.J. Cancer risk in mutation carriers of DNA-mismatch-repair genes. Int. J. Cancer 1999, 81, 214-218. [CrossRef]

26. Woolderink, J.M.; De Bock, G.H.; de Hullu, J.A.; Hollema, H.; Zweemer, R.P.; Slangen, B.F.M.; Gaarenstroom, K.N.; van Beurden, M.; van Doorn, H.C.; Sijmons, R.H.; et al. Characteristics of Lynch syndrome associated ovarian cancer. Gynecol. Oncol. 2018, 150, 324-330. [CrossRef]

27. Bewtra, C.; Watson, P.; Conway, T.; Read-Hippee, C.; Lynch, H.T. Hereditary ovarian cancer: A clinicopathological study. Int. J. Gynecol. Pathol. 1992, 11, 180-187. [CrossRef] [PubMed]

28. Litton, J.K.; Ready, K.; Chen, H.; Gutierrez-Barrera, A.; Etzel, C.J.; Meric-Bernstam, F.; Gonzalez-Angulo, A.M.; Le-Petross, H.; Lu, K.; Hortobagyi, G.N.; et al. Earlier age of onset of BRCA mutation-related cancers in subsequent generations. Cancer 2012, 118, 321-325. [CrossRef] [PubMed]

29. Zhong, Q.; Peng, H.L.; Zhao, X.; Zhang, L.; Hwang, W.T. Effects of BRCA1- and BRCA2-related mutations on ovarian and breast cancer survival: A meta-analysis. Clin. Cancer Res. 2015, 21, 211-220. [CrossRef]

30. Kotsopoulos, J.; Rosen, B.; Fan, I.; Moody, J.; McLaughlin, J.R.; Risch, H.; May, T.; Sun, P.; Narod, S.A. Ten-year survival after epithelial ovarian cancer is not associated with BRCA mutation status. Gynecol. Oncol. 2016, 140, 42-47. [CrossRef]

31. Roy, R.; Chun, J.; Powell, S.N. BRCA1 and BRCA2: Different roles in a common pathway of genome protection. Nat. Rev. Cancer 2011, 12, 68-78. [CrossRef]

32. Candido-dos-Reis, F.J.; Song, H.; Goode, E.L.; Cunningham, J.M.; Fridley, B.L.; Larson, M.C.; Alsop, K.; Dicks, E.; Harrington, P.; Ramus, S.J.; et al. Germline mutation in BRCA1 or BRCA2 and ten-year survival for women diagnosed with epithelial ovarian cancer. Clin. Cancer Res. 2015, 21, 652-657. [CrossRef]

33. Hyman, D.M.; Zhou, Q.; Iasonos, A.; Grisham, R.N.; Arnold, A.G.; Phillips, M.F.; Bhatia, J.; Levine, D.A.; Aghajanian, C.; Offit, K.; et al. Improved survival for BRCA2-associated serous ovarian cancer compared with both BRCA-negative and BRCA1-associated serous ovarian cancer. Cancer 2012, 118, 3703-3709. [CrossRef]

34. Liu, G.; Yang, D.; Sun, Y.; Shmulevich, I.; Xue, F.; Sood, A.K.; Zhang, W. Differing clinical impact of BRCA1 and BRCA2 mutations in serous ovarian cancer. Pharmacogenomics 2012, 13, 1523-1535. [CrossRef]

35. Yang, D.; Khan, S.; Sun, Y.; Hess, K.; Shmulevich, I.; Sood, A.K.; Zhang, W. Association between BRCA2 but not BRCA1 Mutations and Beneficial Survival, Chemotherapy Sensitivity, and Gene Mutator Phenotype in Patients with Ovarian Cancer. JAMA J. Am. Med. Assoc. 2011, 306, 1557-1565. [CrossRef] [PubMed]

36. Buys, S.S.; Partridge, E.; Black, A.; Johnson, C.C.; Lamerato, L.; Isaacs, C.; Reding, D.J.; Greenlee, R.T.; Yokochi, L.A.; Kessel, B.; et al. Effect of screening on ovarian cancer mortality: The Prostate, Lung, Colorectal and Ovarian (PLCO) Cancer Screening Randomized Controlled Trial. JAMA 2011, 305, 2295-2303. [CrossRef]

37. Lewis, K.E.; Lu, K.H.; Klimczak, A.M.; Mok, S.C. Recommendations and Choices for BRCA Mutation Carriers at Risk for Ovarian Cancer: A Complicated Decision. Cancers 2018, 10, 57. [CrossRef] [PubMed]

38. McLaughlin, J.R.; Risch, H.A.; Lubinski, J.; Moller, P.; Ghadirian, P.; Lynch, H.; Karlan, B.; Fishman, D.; Rosen, B.; Neuhausen, S.L.; et al. Reproductive risk factors for ovarian cancer in carriers of BRCA1 or BRCA2 mutations: A case-control study. Lancet. Oncol. 2007, 8, 26-34. [CrossRef]

39. Finch, A.P.; Lubinski, J.; Moller, P.; Singer, C.F.; Karlan, B.; Senter, L.; Rosen, B.; Maehle, L.; Ghadirian, P.; Cybulski, C.; et al. Impact of oophorectomy on cancer incidence and mortality in women with a BRCA1 or BRCA2 mutation. J. Clin. Oncol. 2014, 32, 1547-1553. [CrossRef] [PubMed]

40. Eleje, G.U.; Eke, A.C.; Ezebialu, I.U.; Ikechebelu, J.I.; Ugwu, E.O.; Okonkwo, O.O. Risk-reducing bilateral salpingo-oophorectomy in women with BRCA1 or BRCA2 mutations. Cochrane Database Syst. Rev. 2018, 8, CD012464. [CrossRef] [PubMed] 
41. Antoniou, A.C.; Rookus, M.; Andrieu, N.; Brohet, R.; Chang-Claude, J.; Peock, S.; Cook, M.; Evans, D.G.; Eeles, R.; Nogues, C.; et al. Reproductive and hormonal factors, and ovarian cancer risk for BRCA1 and BRCA2 mutation carriers: Results from the International BRCA1/2 Carrier Cohort Study. Cancer Epidemiol. Biomark. Prev. 2009, 18, 601-610. [CrossRef]

42. Cibula, D.; Widschwendter, M.; Majek, O.; Dusek, L. Tubal ligation and the risk of ovarian cancer: Review and meta-analysis. Hum. Reprod. Update 2011, 17, 55-67. [CrossRef]

43. Bristow, R.E.; Tomacruz, R.S.; Armstrong, D.K.; Trimble, E.L.; Montz, F.J. Survival effect of maximal cytoreductive surgery for advanced ovarian carcinoma during the platinum era: A meta-analysis. J. Clin. Oncol. 2002, 20, 1248-1259. [CrossRef] [PubMed]

44. Hyman, D.M.; Long, K.C.; Tanner, E.J.; Grisham, R.N.; Arnold, A.G.; Bhatia, J.; Phillips, M.F.; Spriggs, D.R.; Soslow, R.A.; Kauff, N.D.; et al. Outcomes of primary surgical cytoreduction in patients with BRCA-associated high-grade serous ovarian carcinoma. Gynecol. Oncol. 2012, 126, 224-228. [CrossRef]

45. Petrillo, M.; Marchetti, C.; De Leo, R.; Musella, A.; Capoluongo, E.; Paris, I.; Benedetti Panici, P.; Scambia, G.; Fagotti, A. BRCA mutational status, initial disease presentation, and clinical outcome in high-grade serous advanced ovarian cancer: A multicenter study. Am. J. Obstet. Gynecol. 2017, 217, 334.e331-334.e339. [CrossRef]

46. Reyes, M.C.; Arnold, A.G.; Kauff, N.D.; Levine, D.A.; Soslow, R.A. Invasion patterns of metastatic high-grade serous carcinoma of ovary or fallopian tube associated with BRCA deficiency. Mod. Pathol. 2014, 27, 1405. [CrossRef] [PubMed]

47. Bois, A.D.; Vergote, I.; Ferron, G.; Reuss, A.; Meier, W.; Greggi, S.; Jensen, P.T.; Selle, F.; Guyon, F.; Pomel, C.; et al. Randomized controlled phase III study evaluating the impact of secondary cytoreductive surgery in recurrent ovarian cancer: AGO DESKTOP III/ENGOT ov20. J. Clin. Oncol. 2017, 35, 5501. [CrossRef]

48. Coleman, R.L.; Enserro, D.; Spirtos, N.; Herzog, T.J.; Sabbatini, P.; Armstrong, D.K.; Kim, B.; Fujiwara, K.; Walker, J.L.; Flynn, P.J.; et al. A phase III randomized controlled trial of secondary surgical cytoreduction (SSC) followed by platinum-based combination chemotherapy (PBC), with or without bevacizumab (B) in platinum-sensitive, recurrent ovarian cancer (PSOC): A NRG Oncology/Gynecol. Oncol. Group (GOG) study. J. Clin. Oncol. 2018, 36, 5501.

49. Harter, P.; du Bois, A.; Hahmann, M.; Hasenburg, A.; Burges, A.; Loibl, S.; Gropp, M.; Huober, J.; Fink, D.; Schroder, W.; et al. Surgery in recurrent ovarian cancer: The Arbeitsgemeinschaft Gynaekologische Onkologie (AGO) DESKTOP OVAR trial. Ann. Surg. Oncol. 2006, 13, 1702-1710. [CrossRef] [PubMed]

50. Harter, P.; Sehouli, J.; Reuss, A.; Hasenburg, A.; Scambia, G.; Cibula, D.; Mahner, S.; Vergote, I.; Reinthaller, A.; Burges, A.; et al. Prospective validation study of a predictive score for operability of recurrent ovarian cancer: The Multicenter Intergroup Study DESKTOP II. A project of the AGO Kommission OVAR, AGO Study Group, NOGGO, AGO-Austria, and MITO. Int. J. Gynecol. Cancer 2011, 21, 289-295. [CrossRef]

51. Chi, D.S.; McCaughty, K.; Diaz, J.P.; Huh, J.; Schwabenbauer, S.; Hummer, A.J.; Venkatraman, E.S.; Aghajanian, C.; Sonoda, Y.; Abu-Rustum, N.R.; et al. Guidelines and selection criteria for secondary cytoreductive surgery in patients with recurrent, platinum-sensitive epithelial ovarian carcinoma. Cancer 2006, 106, 1933-1939. [CrossRef]

52. Tian, W.J.; Chi, D.S.; Sehouli, J.; Trope, C.G.; Jiang, R.; Ayhan, A.; Cormio, G.; Xing, Y.; Breitbach, G.P.; Braicu, E.I.; et al. A risk model for secondary cytoreductive surgery in recurrent ovarian cancer: An evidence-based proposal for patient selection. Ann. Surg. Oncol. 2012, 19, 597-604. [CrossRef]

53. Gourley, C.; Michie, C.O.; Roxburgh, P.; Yap, T.A.; Harden, S.; Paul, J.; Ragupathy, K.; Todd, R.; Petty, R.; Reed, N.; et al. Increased incidence of visceral metastases in scottish patients with BRCA1/2-defective ovarian cancer: An extension of the ovarian BRCAness phenotype. J. Clin. Oncol. 2010, 28, 2505-2511. [CrossRef]

54. Howell, S.B.; Pfeifle, C.L.; Wung, W.E.; Olshen, R.A.; Lucas, W.E.; Yon, J.L.; Green, M. Intraperitoneal cisplatin with systemic thiosulfate protection. Ann. Intern. Med. 1982, 97, 845-851. [CrossRef] [PubMed]

55. Alberts, D.S.; Liu, P.Y.; Hannigan, E.V.; O’Toole, R.; Williams, S.D.; Young, J.A.; Franklin, E.W.; Clarke-Pearson, D.L.; Malviya, V.K.; DuBeshter, B. Intraperitoneal cisplatin plus intravenous cyclophosphamide versus intravenous cisplatin plus intravenous cyclophosphamide for stage III ovarian cancer. N. Engl. J. Med. 1996, 335, 1950-1955. [CrossRef] [PubMed]

56. Armstrong, D.K.; Bundy, B.; Wenzel, L.; Huang, H.Q.; Baergen, R.; Lele, S.; Copeland, L.J.; Walker, J.L.; Burger, R.A. Intraperitoneal cisplatin and paclitaxel in ovarian cancer. N. Engl. J. Med. 2006, 354, 34-43. [CrossRef] [PubMed] 
57. Markman, M.; Bundy, B.N.; Alberts, D.S.; Fowler, J.M.; Clark-Pearson, D.L.; Carson, L.F.; Wadler, S.; Sickel, J. Phase III trial of standard-dose intravenous cisplatin plus paclitaxel versus moderately high-dose carboplatin followed by intravenous paclitaxel and intraperitoneal cisplatin in small-volume stage III ovarian carcinoma: An intergroup study of the Gynecol. Oncol. Group, Southwestern Oncology Group, and Eastern Cooperative Oncology Group. J. Clin. Oncol. 2001, 19, 1001-1007. [PubMed]

58. Tewari, D.; Java, J.J.; Salani, R.; Armstrong, D.K.; Markman, M.; Herzog, T.; Monk, B.J.; Chan, J.K. Long-term survival advantage and prognostic factors associated with intraperitoneal chemotherapy treatment in advanced ovarian cancer: A Gynecol. Oncol. group study. J. Clin. Oncol. 2015, 33, 1460-1466. [CrossRef]

59. Elit, L.; Oliver, T.K.; Covens, A.; Kwon, J.; Fung, M.F.; Hirte, H.W.; Oza, A.M. Intraperitoneal chemotherapy in the first-line treatment of women with stage III epithelial ovarian cancer: A systematic review with metaanalyses. Cancer 2007, 109, 692-702. [CrossRef] [PubMed]

60. Jaaback, K.; Johnson, N.; Lawrie, T.A. Intraperitoneal chemotherapy for the initial management of primary epithelial ovarian cancer. Cochrane Database Syst. Rev. 2016. [CrossRef] [PubMed]

61. Hess, L.M.; Benham-Hutchins, M.; Herzog, T.J.; Hsu, C.H.; Malone, D.C.; Skrepnek, G.H.; Slack, M.K.; Alberts, D.S. A meta-analysis of the efficacy of intraperitoneal cisplatin for the front-line treatment of ovarian cancer. Int. J. Gynecol. Cancer 2007, 17, 561-570. [CrossRef] [PubMed]

62. Lesnock, J.L.; Darcy, K.M.; Tian, C.; Deloia, J.A.; Thrall, M.M.; Zahn, C.; Armstrong, D.K.; Birrer, M.J.; Krivak, T.C. BRCA1 expression and improved survival in ovarian cancer patients treated with intraperitoneal cisplatin and paclitaxel: A Gynecol. Oncol. Group Study. Br. J. Cancer 2013, 108, 1231-1237. [CrossRef]

63. van Driel, W.J.; Koole, S.N.; Sikorska, K.; Schagen van Leeuwen, J.H.; Schreuder, H.W.R.; Hermans, R.H.M.; de Hingh, I.; van der Velden, J.; Arts, H.J.; Massuger, L.; et al. Hyperthermic Intraperitoneal Chemotherapy in Ovarian Cancer. N. Engl. J. Med. 2018, 378, 230-240. [CrossRef]

64. Safra, T.; Grisaru, D.; Inbar, M.; Abu-Abeid, S.; Dayan, D.; Matceyevsky, D.; Weizman, A.; Klausner, J.M. Cytoreduction surgery with hyperthermic intraperitoneal chemotherapy in recurrent ovarian cancer improves progression-free survival, especially in BRCA-positive patients-A case-control study. J. Surg. Oncol. 2014, 110, 661-665. [CrossRef]

65. van den Tempel, N.; Odijk, H.; van Holthe, N.; Naipal, K.; Raams, A.; Eppink, B.; van Gent, D.C.; Hardillo, J.; Verduijn, G.M.; Drooger, J.C.; et al. Heat-induced BRCA2 degradation in human tumours provides rationale for hyperthermia-PARP-inhibitor combination therapies. Int. J. Hyperther. 2018, 34, 407-414. [CrossRef]

66. Krawczyk, P.M.; Eppink, B.; Essers, J.; Stap, J.; Rodermond, H.; Odijk, H.; Zelensky, A.; van Bree, C.; Stalpers, L.J.; Buist, M.R.; et al. Mild hyperthermia inhibits homologous recombination, induces BRCA2 degradation, and sensitizes cancer cells to poly (ADP-ribose) polymerase-1 inhibition. Proc. Natl. Acad. Sci. USA 2011, 108, 9851-9856. [CrossRef]

67. Schaaf, L.; van der Kuip, H.; Zopf, W.; Winter, S.; Munch, M.; Murdter, T.E.; Thon, K.P.; Steurer, W.; Aulitzky, W.E.; Ulmer, C. A Temperature of 40 degrees C Appears to be a Critical Threshold for Potentiating Cytotoxic Chemotherapy In Vitro and in Peritoneal Carcinomatosis Patients Undergoing HIPEC. Ann. Surg. Oncol. 2015, 22, S758-S765. [CrossRef]

68. Poklar, N.; Pilch, D.S.; Lippard, S.J.; Redding, E.A.; Dunham, S.U.; Breslauer, K.J. Influence of cisplatin intrastrand crosslinking on the conformation, thermal stability, and energetics of a 20-mer DNA duplex. Proc. Natl. Acad. Sci. USA 1996, 93, 7606-7611. [CrossRef]

69. Todd, R.C.; Lippard, S.J. Inhibition of transcription by platinum antitumor compounds. Metallomics 2009, 1, 280-291. [CrossRef]

70. Ozols, R.F.; Bundy, B.N.; Greer, B.E.; Fowler, J.M.; Clarke-Pearson, D.; Burger, R.A.; Mannel, R.S.; DeGeest, K.; Hartenbach, E.M.; Baergen, R. Phase III trial of carboplatin and paclitaxel compared with cisplatin and paclitaxel in patients with optimally resected stage III ovarian cancer: A Gynecol. Oncol. Group study. J. Clin. Oncol. 2003, 21, 3194-3200. [CrossRef]

71. du Bois, A.; Luck, H.J.; Meier, W.; Adams, H.P.; Mobus, V.; Costa, S.; Bauknecht, T.; Richter, B.; Warm, M.; Schroder, W.; et al. A randomized clinical trial of cisplatin/paclitaxel versus carboplatin/paclitaxel as first-line treatment of ovarian cancer. J. Nat. Cancer Inst. 2003, 95, 1320-1329. [CrossRef]

72. Pfisterer, J.; Plante, M.; Vergote, I.; du Bois, A.; Hirte, H.; Lacave, A.J.; Wagner, U.; Stahle, A.; Stuart, G.; Kimmig, R.; et al. Gemcitabine plus carboplatin compared with carboplatin in patients with platinum-sensitive recurrent ovarian cancer: An intergroup trial of the AGO-OVAR, the NCIC CTG, and the EORTC GCG. J. Clin. Oncol. 2006, 24, 4699-4707. [CrossRef] 
73. Pujade-Lauraine, E.; Wagner, U.; Aavall-Lundqvist, E.; Gebski, V.; Heywood, M.; Vasey, P.A.; Volgger, B.; Vergote, I.; Pignata, S.; Ferrero, A.; et al. Pegylated liposomal Doxorubicin and Carboplatin compared with Paclitaxel and Carboplatin for patients with platinum-sensitive ovarian cancer in late relapse. J. Clin. Oncol. 2010, 28, 3323-3329. [CrossRef] [PubMed]

74. Parmar, M.K.; Ledermann, J.A.; Colombo, N.; du Bois, A.; Delaloye, J.F.; Kristensen, G.B.; Wheeler, S.; Swart, A.M.; Qian, W.; Torri, V.; et al. Paclitaxel plus platinum-based chemotherapy versus conventional platinum-based chemotherapy in women with relapsed ovarian cancer: The ICON4/AGO-OVAR-2.2 trial. Lancet 2003, 361, 2099-2106. [PubMed]

75. Quinn, J.E.; Carser, J.E.; James, C.R.; Kennedy, R.D.; Harkin, D.P. BRCA1 and implications for response to chemotherapy in ovarian cancer. Gynecol. Oncol. 2009, 113, 134-142. [CrossRef]

76. Quinn, J.E.; James, C.R.; Stewart, G.E.; Mulligan, J.M.; White, P.; Chang, G.K.; Mullan, P.B.; Johnston, P.G.; Wilson, R.H.; Harkin, D.P. BRCA1 mRNA expression levels predict for overall survival in ovarian cancer after chemotherapy. Clin. Cancer Res. 2007, 13, 7413-7420. [CrossRef] [PubMed]

77. Samouelian, V.; Maugard, C.M.; Jolicoeur, M.; Bertrand, R.; Arcand, S.L.; Tonin, P.N.; Provencher, D.M.; Mes-Masson, A.M. Chemosensitivity and radiosensitivity profiles of four new human epithelial ovarian cancer cell lines exhibiting genetic alterations in BRCA2, TGFbeta-RII, KRAS2, TP53 and/or CDNK2A. Cancer Chemother. Pharmacol. 2004, 54, 497-504. [CrossRef]

78. Bartz, S.R.; Zhang, Z.; Burchard, J.; Imakura, M.; Martin, M.; Palmieri, A.; Needham, R.; Guo, J.; Gordon, M.; Chung, N.; et al. Small interfering RNA screens reveal enhanced cisplatin cytotoxicity in tumor cells having both BRCA network and TP53 disruptions. Mol. Cell. Biol. 2006, 26, 9377-9386. [CrossRef]

79. Tassone, P.; Di Martino, M.T.; Ventura, M.; Pietragalla, A.; Cucinotto, I.; Calimeri, T.; Bulotta, A.; Neri, P.; Caraglia, M.; Tagliaferri, P. Loss of BRCA1 function increases the antitumor activity of cisplatin against human breast cancer xenografts in vivo. Cancer Biol. Ther. 2009, 8, 648-653. [CrossRef]

80. Xing, D.; Orsulic, S. A mouse model for the molecular characterization of brca1-associated ovarian carcinoma. Cancer Res. 2006, 66, 8949-8953. [CrossRef]

81. Tan, D.S.; Rothermundt, C.; Thomas, K.; Bancroft, E.; Eeles, R.; Shanley, S.; Ardern-Jones, A.; Norman, A.; Kaye, S.B.; Gore, M.E. "BRCAness" syndrome in ovarian cancer: A case-control study describing the clinical features and outcome of patients with epithelial ovarian cancer associated with BRCA1 and BRCA2 mutations. J. Clin. Oncol. 2008, 26, 5530-5536. [CrossRef] [PubMed]

82. Vencken, P.M.; Kriege, M.; Hoogwerf, D.; Beugelink, S.; van der Burg, M.E.; Hooning, M.J.; Berns, E.M.; Jager, A.; Collee, M.; Burger, C.W.; et al. Chemosensitivity and outcome of BRCA1- and BRCA2-associated ovarian cancer patients after first-line chemotherapy compared with sporadic ovarian cancer patients. Ann. Oncol. 2011, 22, 1346-1352. [CrossRef] [PubMed]

83. Alsop, K.; Fereday, S.; Meldrum, C.; deFazio, A.; Emmanuel, C.; George, J.; Dobrovic, A.; Birrer, M.J.; Webb, P.M.; Stewart, C.; et al. BRCA mutation frequency and patterns of treatment response in BRCA mutation-positive women with ovarian cancer: A report from the Australian Ovarian Cancer Study Group. J. Clin. Oncol. 2012, 30, 2654-2663. [CrossRef] [PubMed]

84. Gorodnova, T.V.; Sokolenko, A.P.; Ivantsov, A.O.; Iyevleva, A.G.; Suspitsin, E.N.; Aleksakhina, S.N.; Yanus, G.A.; Togo, A.V.; Maximov, S.Y.; Imyanitov, E.N. High response rates to neoadjuvant platinum-based therapy in ovarian cancer patients carrying germ-line BRCA mutation. Cancer Lett 2015, 369, 363-367. [CrossRef] [PubMed]

85. Davies, A.A.; Masson, J.Y.; McIlwraith, M.J.; Stasiak, A.Z.; Stasiak, A.; Venkitaraman, A.R.; West, S.C. Role of BRCA2 in control of the RAD51 recombination and DNA repair protein. Mol. Cell 2001, 7, 273-282. [CrossRef]

86. Pennington, K.P.; Walsh, T.; Harrell, M.I.; Lee, M.K.; Pennil, C.C.; Rendi, M.H.; Thornton, A.; Norquist, B.M.; Casadei, S.; Nord, A.S.; et al. Germline and somatic mutations in homologous recombination genes predict platinum response and survival in ovarian, fallopian tube, and peritoneal carcinomas. Clin. Cancer Res. 2014, 20, 764-775. [CrossRef]

87. Barbuti, A.M.; Chen, Z.S. Paclitaxel Through the Ages of Anticancer Therapy: Exploring Its Role in Chemoresistance and Radiation Therapy. Cancers 2015, 7, 2360-2371. [CrossRef]

88. Piccart, M.J.; Bertelsen, K.; James, K.; Cassidy, J.; Mangioni, C.; Simonsen, E.; Stuart, G.; Kaye, S.; Vergote, I.; Blom, R.; et al. Randomized intergroup trial of cisplatin-paclitaxel versus cisplatin-cyclophosphamide in women with advanced epithelial ovarian cancer: Three-year results. J. Nat. Cancer Inst. 2000, 92, 699-708. [CrossRef] 
89. Ten Bokkel Huinink, W.; Gore, M.; Carmichael, J.; Gordon, A.; Malfetano, J.; Hudson, I.; Broom, C.; Scarabelli, C.; Davidson, N.; Spanczynski, M.; et al. Topotecan versus paclitaxel for the treatment of recurrent epithelial ovarian cancer. J. Clin. Oncol. 1997, 15, 2183-2193. [CrossRef] [PubMed]

90. Markman, M.; Blessing, J.; Rubin, S.C.; Connor, J.; Hanjani, P.; Waggoner, S. Phase II trial of weekly paclitaxel $\left(80 \mathrm{mg} / \mathrm{m}^{2}\right)$ in platinum and paclitaxel-resistant ovarian and primary peritoneal cancers: A Gynecol. Oncol. Group study. Gynecol. Oncol. 2006, 101, 436-440. [CrossRef]

91. Luvero, D.; Milani, A.; Ledermann, J.A. Treatment options in recurrent ovarian cancer: Latest evidence and clinical potential. Ther. Adv. Med. Oncol. 2014, 6, 229-239. [CrossRef] [PubMed]

92. Kerbel, R.S.; Kamen, B.A. The anti-angiogenic basis of metronomic chemotherapy. Nat. Rev. Cancer 2004, 4, 423-436. [CrossRef]

93. Katsumata, N.; Yasuda, M.; Isonishi, S.; Takahashi, F.; Michimae, H.; Kimura, E.; Aoki, D.; Jobo, T.; Kodama, S.; Terauchi, F.; et al. Long-term results of dose-dense paclitaxel and carboplatin versus conventional paclitaxel and carboplatin for treatment of advanced epithelial ovarian, fallopian tube, or primary peritoneal cancer (JGOG 3016): A randomised, controlled, open-label trial. Lancet Oncol. 2013, 14, 1020-1026. [CrossRef]

94. Clamp, A.R.; McNeish, I.; Dean, A.; Gallardo, D.; Weon-Kim, J.; O’Donnell, D.; Hook, J.; Coyle, C.; Blagden, S.P.; Brenton, J.; et al. 929O_PRICON8: A GCIG phase III randomised trial evaluating weekly dose- dense chemotherapy integration in first-line epithelial ovarian/fallopian tube/primary peritoneal carcinoma (EOC) treatment: Results of primary progression- free survival (PFS) analysis. Ann. Oncol. 2017, 28, mdx440.039.

95. Pignata, S.; Scambia, G.; Katsaros, D.; Gallo, C.; Pujade-Lauraine, E.; De Placido, S.; Bologna, A.; Weber, B.; Raspagliesi, F.; Panici, P.B.; et al. Carboplatin plus paclitaxel once a week versus every 3 weeks in patients with advanced ovarian cancer (MITO-7): A randomised, multicentre, open-label, phase 3 trial. Lancet. Oncol. 2014, 15, 396-405. [CrossRef]

96. Rosenberg, P.; Andersson, H.; Boman, K.; Ridderheim, M.; Sorbe, B.; Puistola, U.; Paro, G. Randomized trial of single agent paclitaxel given weekly versus every three weeks and with peroral versus intravenous steroid premedication to patients with ovarian cancer previously treated with platinum. Acta Oncol. 2002, 41, 418-424. [CrossRef]

97. Safra, T.; Rogowski, O.; Muggia, F.M. The effect of germ-line BRCA mutations on response to chemotherapy and outcome of recurrent ovarian cancer. Int. J. Gynecol. Cancer 2014, 24, 488-495. [CrossRef]

98. Nientiedt, C.; Heller, M.; Endris, V.; Volckmar, A.L.; Zschabitz, S.; Tapia-Laliena, M.A.; Duensing, A.; Jager, D.; Schirmacher, P.; Sultmann, H.; et al. Mutations in BRCA2 and taxane resistance in prostate cancer. Sci. Rep. 2017, 7, 4574. [CrossRef] [PubMed]

99. Kriege, M.; Jager, A.; Hooning, M.J.; Huijskens, E.; Blom, J.; van Deurzen, C.H.; Bontenbal, M.; Collee, J.M.; Menke-Pluijmers, M.B.; Martens, J.W.; et al. The efficacy of taxane chemotherapy for metastatic breast cancer in BRCA1 and BRCA2 mutation carriers. Cancer 2012, 118, 899-907. [CrossRef]

100. Soares, D.G.; Escargueil, A.E.; Poindessous, V.; Sarasin, A.; de Gramont, A.; Bonatto, D.; Henriques, J.A.; Larsen, A.K. Replication and homologous recombination repair regulate DNA double-strand break formation by the antitumor alkylator ecteinascidin 743. Proc. Natl. Acad. Sci. USA 2007, 104, 13062-13067. [CrossRef] [PubMed]

101. Monk, B.J.; Lorusso, D.; Italiano, A.; Kaye, S.B.; Aracil, M.; Tanovic, A.; D'Incalci, M. Trabectedin as a chemotherapy option for patients with BRCA deficiency. Cancer Treat. Rev. 2016, 50, 175-182. [CrossRef]

102. Monk, B.J.; Herzog, T.J.; Kaye, S.B.; Krasner, C.N.; Vermorken, J.B.; Muggia, F.M.; Pujade-Lauraine, E.; Lisyanskaya, A.S.; Makhson, A.N.; Rolski, J.; et al. Trabectedin plus pegylated liposomal Doxorubicin in recurrent ovarian cancer. J. Clin. Oncol. 2010, 28, 3107-3114. [CrossRef]

103. Poveda, A.; Vergote, I.; Tjulandin, S.; Kong, B.; Roy, M.; Chan, S.; Filipczyk-Cisarz, E.; Hagberg, H.; Kaye, S.B.; Colombo, N.; et al. Trabectedin plus pegylated liposomal doxorubicin in relapsed ovarian cancer: Outcomes in the partially platinum-sensitive (platinum-free interval 6-12 months) subpopulation of OVA-301 phase III randomized trial. Ann. Oncol. 2011, 22, 39-48. [CrossRef]

104. Monk, B.J.; Herzog, T.J.; Kaye, S.B.; Krasner, C.N.; Vermorken, J.B.; Muggia, F.M.; Pujade-Lauraine, E.; Park, Y.C.; Parekh, T.V.; Poveda, A.M. Trabectedin plus pegylated liposomal doxorubicin (PLD) versus PLD in recurrent ovarian cancer: Overall survival analysis. Eur. J. Cancer 2012, 48, 2361-2368. [CrossRef] [PubMed] 
105. Monk, B.J.; Ghatage, P.; Parekh, T.; Henitz, E.; Knoblauch, R.; Matos-Pita, A.S.; Nieto, A.; Park, Y.C.; Cheng, P.S.; Li, W.; et al. Effect of BRCA1 and XPG mutations on treatment response to trabectedin and pegylated liposomal doxorubicin in patients with advanced ovarian cancer: Exploratory analysis of the phase 3 OVA-301 study. Ann. Oncol. 2015, 26, 914-920. [CrossRef]

106. Lorusso, D.; Scambia, G.; Pignata, S.; Sorio, R.; Amadio, G.; Lepori, S.; Mosconi, A.; Pisano, C.; Mangili, G.; Maltese, G.; et al. Prospective phase II trial of trabectedin in BRCA-mutated and/or BRCAness phenotype recurrent ovarian cancer patients: The MITO 15 trial. Ann. Oncol. 2016, 27, 487-493. [CrossRef] [PubMed]

107. Gabizon, A.A.; Patil, Y.; La-Beck, N.M. New insights and evolving role of pegylated liposomal doxorubicin in cancer therapy. Drug Resist. Updat 2016, 29, 90-106. [CrossRef] [PubMed]

108. Wagner, U.; Marth, C.; Largillier, R.; Kaern, J.; Brown, C.; Heywood, M.; Bonaventura, T.; Vergote, I.; Piccirillo, M.C.; Fossati, R.; et al. Final overall survival results of phase III GCIG CALYPSO trial of pegylated liposomal doxorubicin and carboplatin vs paclitaxel and carboplatin in platinum-sensitive ovarian cancer patients. Br. J. Cancer 2012, 107, 588-591. [CrossRef]

109. Gordon, A.N.; Fleagle, J.T.; Guthrie, D.; Parkin, D.E.; Gore, M.E.; Lacave, A.J. Recurrent epithelial ovarian carcinoma: A randomized phase III study of pegylated liposomal doxorubicin versus topotecan. J. Clin. Oncol. 2001, 19, 3312-3322. [CrossRef]

110. Gordon, A.N.; Tonda, M.; Sun, S.; Rackoff, W. Long-term survival advantage for women treated with pegylated liposomal doxorubicin compared with topotecan in a phase 3 randomized study of recurrent and refractory epithelial ovarian cancer. Gynecol. Oncol. 2004, 95, 1-8. [CrossRef] [PubMed]

111. Pignata, S.; Scambia, G.; Ferrandina, G.; Savarese, A.; Sorio, R.; Breda, E.; Gebbia, V.; Musso, P.; Frigerio, L.; Del Medico, P.; et al. Carboplatin plus paclitaxel versus carboplatin plus pegylated liposomal doxorubicin as first-line treatment for patients with ovarian cancer: The MITO-2 randomized phase III trial. J. Clin. Oncol. 2011, 29, 3628-3635. [CrossRef] [PubMed]

112. Mahner, S.; Meier, W.; du Bois, A.; Brown, C.; Lorusso, D.; Dell'Anna, T.; Cretin, J.; Havsteen, H.; Bessette, P.; Zeimet, A.G.; et al. Carboplatin and pegylated liposomal doxorubicin versus carboplatin and paclitaxel in very platinum-sensitive ovarian cancer patients: Results from a subset analysis of the CALYPSO phase III trial. Eur. J. Cancer 2015, 51, 352-358. [CrossRef] [PubMed]

113. Adams, S.F.; Marsh, E.B.; Elmasri, W.; Halberstadt, S.; Vandecker, S.; Sammel, M.D.; Bradbury, A.R.; Daly, M.; Karlan, B.; Rubin, S.C. A high response rate to liposomal doxorubicin is seen among women with BRCA mutations treated for recurrent epithelial ovarian cancer. Gynecol. Oncol. 2011, 123, 486-491. [CrossRef] [PubMed]

114. Safra, T.; Borgato, L.; Nicoletto, M.O.; Rolnitzky, L.; Pelles-Avraham, S.; Geva, R.; Donach, M.E.; Curtin, J.; Novetsky, A.; Grenader, T.; et al. BRCA mutation status and determinant of outcome in women with recurrent epithelial ovarian cancer treated with pegylated liposomal doxorubicin. Mol. Cancer Ther. 2011, 10, 2000-2007. [CrossRef] [PubMed]

115. Kaye, S.B.; Lubinski, J.; Matulonis, U.; Ang, J.E.; Gourley, C.; Karlan, B.Y.; Amnon, A.; Bell-McGuinn, K.M.; Chen, L.M.; Friedlander, M.; et al. Phase II, open-label, randomized, multicenter study comparing the efficacy and safety of olaparib, a poly (ADP-ribose) polymerase inhibitor, and pegylated liposomal doxorubicin in patients with BRCA1 or BRCA2 mutations and recurrent ovarian cancer. J. Clin. Oncol. 2012, 30, 372-379. [CrossRef] [PubMed]

116. Gibson, B.A.; Kraus, W.L. New insights into the molecular and cellular functions of poly(ADP-ribose) and PARPs. Nat. Rev. Mol. Cell Biol. 2012, 13, 411-424. [CrossRef]

117. Ame, J.C.; Spenlehauer, C.; de Murcia, G. The PARP superfamily. Bioessays 2004, 26, 882-893. [CrossRef] [PubMed]

118. Malanga, M.; Althaus, F.R. The role of poly(ADP-ribose) in the DNA damage signaling network. Biochem. Cell Biol. 2005, 83, 354-364. [CrossRef]

119. Kaelin, W.G., Jr. The concept of synthetic lethality in the context of anticancer therapy. Nat. Rev. Cancer 2005, 5, 689-698. [CrossRef]

120. Noel, G.; Giocanti, N.; Fernet, M.; Megnin-Chanet, F.; Favaudon, V. Poly(ADP-ribose) polymerase (PARP-1) is not involved in DNA double-strand break recovery. BMC Cell Biol. 2003, 4, 7. [CrossRef]

121. Helleday, T.; Petermann, E.; Lundin, C.; Hodgson, B.; Sharma, R.A. DNA repair pathways as targets for cancer therapy. Nat. Rev. Cancer 2008, 8, 193-204. [CrossRef] [PubMed] 
122. Farmer, H.; McCabe, N.; Lord, C.J.; Tutt, A.N.; Johnson, D.A.; Richardson, T.B.; Santarosa, M.; Dillon, K.J.; Hickson, I.; Knights, C.; et al. Targeting the DNA repair defect in BRCA mutant cells as a therapeutic strategy. Nature 2005, 434, 917-921. [CrossRef]

123. Kaufman, B.; Shapira-Frommer, R.; Schmutzler, R.K.; Audeh, M.W.; Friedlander, M.; Balmana, J.; Mitchell, G.; Fried, G.; Stemmer, S.M.; Hubert, A.; et al. Olaparib monotherapy in patients with advanced cancer and a germline BRCA1/2 mutation. J. Clin. Oncol. 2015, 33, 244-250. [CrossRef]

124. Domchek, S.M.; Aghajanian, C.; Shapira-Frommer, R.; Schmutzler, R.K.; Audeh, M.W.; Friedlander, M.; Balmana, J.; Mitchell, G.; Fried, G.; Stemmer, S.M.; et al. Efficacy and safety of olaparib monotherapy in germline BRCA1/2 mutation carriers with advanced ovarian cancer and three or more lines of prior therapy. Gynecol. Oncol. 2016, 140, 199-203. [CrossRef] [PubMed]

125. Kim, G.; Ison, G.; McKee, A.E.; Zhang, H.; Tang, S.; Gwise, T.; Sridhara, R.; Lee, E.; Tzou, A.; Philip, R.; et al. FDA Approval Summary: Olaparib Monotherapy in Patients with Deleterious Germline BRCA-Mutated Advanced Ovarian Cancer Treated with Three or More Lines of Chemotherapy. Clin. Cancer Res. 2015, 21, 4257-4261. [CrossRef] [PubMed]

126. Swisher, E.M.; Lin, K.K.; Oza, A.M.; Scott, C.L.; Giordano, H.; Sun, J.; Konecny, G.E.; Coleman, R.L.; Tinker, A.V.; O'Malley, D.M.; et al. Rucaparib in relapsed, platinum-sensitive high-grade ovarian carcinoma (ARIEL2 Part 1): An international, multicentre, open-label, phase 2 trial. Lancet. Oncol. 2017, 18, 75-87. [CrossRef]

127. Fong, P.C.; Yap, T.A.; Boss, D.S.; Carden, C.P.; Mergui-Roelvink, M.; Gourley, C.; De Greve, J.; Lubinski, J.; Shanley, S.; Messiou, C.; et al. Poly(ADP)-ribose polymerase inhibition: Frequent durable responses in BRCA carrier ovarian cancer correlating with platinum-free interval. J. Clin. Oncol. 2010, 28, 2512-2519. [CrossRef]

128. Gelmon, K.A.; Tischkowitz, M.; Mackay, H.; Swenerton, K.; Robidoux, A.; Tonkin, K.; Hirte, H.; Huntsman, D.; Clemons, M.; Gilks, B.; et al. Olaparib in patients with recurrent high-grade serous or poorly differentiated ovarian carcinoma or triple-negative breast cancer: A phase 2, multicentre, open-label, non-randomised study. Lancet. Oncol. 2011, 12, 852-861. [CrossRef]

129. Audeh, M.W.; Carmichael, J.; Penson, R.T.; Friedlander, M.; Powell, B.; Bell-McGuinn, K.M.; Scott, C.; Weitzel, J.N.; Oaknin, A.; Loman, N.; et al. Oral poly(ADP-ribose) polymerase inhibitor olaparib in patients with BRCA1 or BRCA2 mutations and recurrent ovarian cancer: A proof-of-concept trial. Lancet 2010, 376, 245-251. [CrossRef]

130. Sandhu, S.K.; Schelman, W.R.; Wilding, G.; Moreno, V.; Baird, R.D.; Miranda, S.; Hylands, L.; Riisnaes, R.; Forster, M.; Omlin, A.; et al. The poly(ADP-ribose) polymerase inhibitor niraparib (MK4827) in BRCA mutation carriers and patients with sporadic cancer: A phase 1 dose-escalation trial. Lancet. Oncol. 2013, 14, 882-892. [CrossRef]

131. Oza, A.M.; Tinker, A.V.; Oaknin, A.; Shapira-Frommer, R.; McNeish, I.A.; Swisher, E.M.; Ray-Coquard, I.; Bell-McGuinn, K.; Coleman, R.L.; O'Malley, D.M.; et al. Antitumor activity and safety of the PARP inhibitor rucaparib in patients with high-grade ovarian carcinoma and a germline or somatic BRCA1 or BRCA2 mutation: Integrated analysis of data from Study 10 and ARIEL2. Gynecol. Oncol. 2017, 147, 267-275. [CrossRef] [PubMed]

132. Steffensen, K.D.; Adimi, P.; Jakobsen, A. Veliparib Monotherapy to Patients With BRCA Germ Line Mutation and Platinum-Resistant or Partially Platinum-Sensitive Relapse of Epithelial Ovarian Cancer: A Phase I/II Study. Int. J. Gynecol. Cancer 2017, 27, 1842-1849. [CrossRef] [PubMed]

133. de Bono, J.; Ramanathan, R.K.; Mina, L.; Chugh, R.; Glaspy, J.; Rafii, S.; Kaye, S.; Sachdev, J.; Heymach, J.; Smith, D.C.; et al. Phase I, Dose-Escalation, Two-Part Trial of the PARP Inhibitor Talazoparib in Patients with Advanced Germline BRCA1/2 Mutations and Selected Sporadic Cancers. Cancer Discov. 2017, 7, 620-629. [CrossRef] [PubMed]

134. Mateo, J.; Moreno, V.; Gupta, A.; Kaye, S.B.; Dean, E.; Middleton, M.R.; Friedlander, M.; Gourley, C.; Plummer, R.; Rustin, G.; et al. An Adaptive Study to Determine the Optimal Dose of the Tablet Formulation of the PARP Inhibitor Olaparib. Target. Oncol. 2016, 11, 401-415. [CrossRef]

135. Moore, K.N.; Secord, A.A.; Geller, M.A.; Miller, D.S.; Cloven, N.G.; Fleming, G.F.; Wahner Hendrickson, A.E.; Azodi, M.; DiSilvestro, P.; Oza, A.M.; et al. QUADRA: A phase 2, open-label, single-arm study to evaluate niraparib in patients (pts) with relapsed ovarian cancer (ROC) who have received $\geq 3$ prior chemotherapy regimens. J. Clin. Oncol. 2018, 36, 5514. [CrossRef] 
136. Drew, Y.; Ledermann, J.; Hall, G.; Rea, D.; Glasspool, R.; Highley, M.; Jayson, G.; Sludden, J.; Murray, J.; Jamieson, D.; et al. Phase 2 multicentre trial investigating intermittent and continuous dosing schedules of the poly(ADP-ribose) polymerase inhibitor rucaparib in germline BRCA mutation carriers with advanced ovarian and breast cancer. Br. J. Cancer 2016, 114, 723-730. [CrossRef] [PubMed]

137. Kristeleit, R.; Shapiro, G.I.; Burris, H.A.; Oza, A.M.; LoRusso, P.; Patel, M.R.; Domchek, S.M.; Balmana, J.; Drew, Y.; Chen, L.M.; et al. A Phase I-II Study of the Oral PARP Inhibitor Rucaparib in Patients with Germline BRCA1/2-Mutated Ovarian Carcinoma or Other Solid Tumors. Clin. Cancer Res. 2017, 23, 4095-4106. [CrossRef]

138. Coleman, R.L.; Sill, M.W.; Bell-McGuinn, K.; Aghajanian, C.; Gray, H.J.; Tewari, K.S.; Rubin, S.C.; Rutherford, T.J.; Chan, J.K.; Chen, A.; et al. A phase II evaluation of the potent, highly selective PARP inhibitor veliparib in the treatment of persistent or recurrent epithelial ovarian, fallopian tube, or primary peritoneal cancer in patients who carry a germline BRCA1 or BRCA2 mutation-An NRG Oncology/Gynecol. Oncol. Group study. Gynecol. Oncol. 2015, 137, 386-391.

139. Moore, K.; Colombo, N.; Scambia, G.; Kim, B.G.; Oaknin, A.; Friedlander, M.; Lisyanskaya, A.; Floquet, A.; Leary, A.; Sonke, G.S.; et al. Maintenance Olaparib in Patients with Newly Diagnosed Advanced Ovarian Cancer. N. Engl. J. Med. 2018, 379, 2495-2505. [CrossRef] [PubMed]

140. Ledermann, J.; Harter, P.; Gourley, C.; Friedlander, M.; Vergote, I.; Rustin, G.; Scott, C.; Meier, W.; Shapira-Frommer, R.; Safra, T.; et al. Olaparib maintenance therapy in platinum-sensitive relapsed ovarian cancer. N. Engl. J. Med. 2012, 366, 1382-1392. [CrossRef] [PubMed]

141. Ledermann, J.; Harter, P.; Gourley, C.; Friedlander, M.; Vergote, I.; Rustin, G.; Scott, C.L.; Meier, W.; Shapira-Frommer, R.; Safra, T.; et al. Olaparib maintenance therapy in patients with platinum-sensitive relapsed serous ovarian cancer: A preplanned retrospective analysis of outcomes by BRCA status in a randomised phase 2 trial. Lancet Oncol. 2014, 15, 852-861. [CrossRef]

142. Ledermann, J.A.; Harter, P.; Gourley, C.; Friedlander, M.; Vergote, I.; Rustin, G.; Scott, C.; Meier, W.; Shapira-Frommer, R.; Safra, T.; et al. Overall survival in patients with platinum-sensitive recurrent serous ovarian cancer receiving olaparib maintenance monotherapy: An updated analysis from a randomised, placebo-controlled, double-blind, phase 2 trial. Lancet. Oncol. 2016, 17, 1579-1589. [CrossRef]

143. Pujade-Lauraine, E.; Ledermann, J.A.; Selle, F.; Gebski, V.; Penson, R.T.; Oza, A.M.; Korach, J.; Huzarski, T.; Poveda, A.; Pignata, S.; et al. Olaparib tablets as maintenance therapy in patients with platinum-sensitive, relapsed ovarian cancer and a BRCA1/2 mutation (SOLO2/ENGOT-Ov21): A double-blind, randomised, placebo-controlled, phase 3 trial. Lancet Oncol. 2017, 18, 1274-1284. [CrossRef]

144. Mirza, M.R.; Monk, B.J.; Herrstedt, J.; Oza, A.M.; Mahner, S.; Redondo, A.; Fabbro, M.; Ledermann, J.A.; Lorusso, D.; Vergote, I.; et al. Niraparib Maintenance Therapy in Platinum-Sensitive, Recurrent Ovarian Cancer. N. Engl. J. Med. 2016, 375, 2154-2164. [CrossRef] [PubMed]

145. Coleman, R.L.; Oza, A.M.; Lorusso, D.; Aghajanian, C.; Oaknin, A.; Dean, A.; Colombo, N.; Weberpals, J.I.; Clamp, A.; Scambia, G.; et al. Rucaparib maintenance treatment for recurrent ovarian carcinoma after response to platinum therapy (ARIEL3): A randomised, double-blind, placebo-controlled, phase 3 trial. Lancet 2017, 390, 1949-1961. [CrossRef]

146. Travis, L.B.; Holowaty, E.J.; Bergfeldt, K.; Lynch, C.F.; Kohler, B.A.; Wiklund, T.; Curtis, R.E.; Hall, P.; Andersson, M.; Pukkala, E.; et al. Risk of leukemia after platinum-based chemotherapy for ovarian cancer. N. Engl. J. Med. 1999, 340, 351-357. [CrossRef] [PubMed]

147. Korach, J.; Turner, S.; Milenkova, T.; Alecu, I.; McMurtry, E.; Bloomfield, R.; Pujade-Lauraine, E. Incidence of myelodysplastic syndrome (MDS) and acute myeloid leukemia (AML) in patients (pts) with a germline (g) BRCA mutation $(\mathrm{m})$ and platinum-sensitive relapsed ovarian cancer (PSR OC) receiving maintenance olaparib in SOLO2: Impact of prior lines of platinum therapy. J. Clin. Oncol. 2018, 36. [CrossRef]

148. Zhong, L.; Tran, A.T.; Tomasino, T.; Nugent, E.; Smith, J.A. Cost-Effectiveness of Niraparib and Olaparib as Maintenance Therapy for Patients with Platinum-Sensitive Recurrent Ovarian Cancer. J. Manag. Care Spec. Pharm. 2018, 24, 1219-1228. [PubMed]

149. Oza, A.M.; Cibula, D.; Benzaquen, A.O.; Poole, C.; Mathijssen, R.H.; Sonke, G.S.; Colombo, N.; Spacek, J.; Vuylsteke, P.; Hirte, H.; et al. Olaparib combined with chemotherapy for recurrent platinum-sensitive ovarian cancer: A randomised phase 2 trial. Lancet Oncol. 2015, 16, 87-97. [CrossRef] 
150. Lheureux, S.; Lai, Z.; Dougherty, B.A.; Runswick, S.; Hodgson, D.R.; Timms, K.M.; Lanchbury, J.S.; Kaye, S.; Gourley, C.; Bowtell, D.; et al. Long-Term Responders on Olaparib Maintenance in High-Grade Serous Ovarian Cancer: Clinical and Molecular Characterization. Clin. Cancer Res. 2017, 23, 4086-4094. [CrossRef] [PubMed]

151. Lheureux, S.; Bruce, J.P.; Burnier, J.V.; Karakasis, K.; Shaw, P.A.; Clarke, B.A.; Yang, S.Y.; Quevedo, R.; Li, T.; Dowar, M.; et al. Somatic BRCA1/2 Recovery as a Resistance Mechanism After Exceptional Response to Poly (ADP-ribose) Polymerase Inhibition. J. Clin. Oncol. 2017, 35, 1240-1249. [CrossRef] [PubMed]

152. Del Conte, G.; Sessa, C.; von Moos, R.; Vigano, L.; Digena, T.; Locatelli, A.; Gallerani, E.; Fasolo, A.; Tessari, A.; Cathomas, R.; et al. Phase I study of olaparib in combination with liposomal doxorubicin in patients with advanced solid tumours. Br. J. Cancer 2014, 111, 651-659. [CrossRef]

153. Bindra, R.S.; Gibson, S.L.; Meng, A.; Westermark, U.; Jasin, M.; Pierce, A.J.; Bristow, R.G.; Classon, M.K.; Glazer, P.M. Hypoxia-induced down-regulation of BRCA1 expression by E2Fs. Cancer Res. 2005, 65, 11597-11604. [CrossRef] [PubMed]

154. Bindra, R.S.; Schaffer, P.J.; Meng, A.; Woo, J.; Maseide, K.; Roth, M.E.; Lizardi, P.; Hedley, D.W.; Bristow, R.G.; Glazer, P.M. Down-regulation of Rad51 and decreased homologous recombination in hypoxic cancer cells. Mol. Cell. Biol. 2004, 24, 8504-8518. [CrossRef] [PubMed]

155. Lim, J.J.; Yang, K.; Taylor-Harding, B.; Wiedemeyer, W.R.; Buckanovich, R.J. VEGFR3 inhibition chemosensitizes ovarian cancer stemlike cells through down-regulation of BRCA1 and BRCA2. Neoplasia 2014, 16, 343-353.e341-342. [CrossRef]

156. Chan, N.; Bristow, R.G. "Contextual" synthetic lethality and/or loss of heterozygosity: Tumor hypoxia and modification of DNA repair. Clin. Cancer Res. 2010, 16, 4553-4560. [CrossRef] [PubMed]

157. Liu, J.F.; Barry, W.T.; Birrer, M.; Lee, J.M.; Buckanovich, R.J.; Fleming, G.F.; Rimel, B.; Buss, M.K.; Nattam, S.; Hurteau, J.; et al. Combination cediranib and olaparib versus olaparib alone for women with recurrent platinum-sensitive ovarian cancer: A randomised phase 2 study. Lancet Oncol. 2014, 15, 1207-1214. [CrossRef]

158. Liu, J.F.; Barry, W.T.; Birrer, M.J.; Lee, J.-m.; Buckanovich, R.J.; Fleming, G.F.; Rimel, B.; Buss, M.K.; Nattam, S.R.; Hurteau, J.; et al. Overall survival and updated progression-free survival results from a randomized phase 2 trial comparing the combination of olaparib and cediranib against olaparib alone in recurrent platinum-sensitive ovarian cancer. J. Clin. Oncol. 2017, 35, 5535. [CrossRef]

159. Liu, J.F.; Barry, W.T.; Wenham, R.M.; Wahner Hendrickson, A.E.; Armstrong, D.K.; Chan, N.; Cohn, D.E.; Lee, J.M.; Penson, R.T.; Cristea, M.C.; et al. A phase 2 biomarker trial of combination cediranib and olaparib in relapsed platinum (plat) sensitive and plat resistant ovarian cancer (ovca). J. Clin. Oncol. 2018, 36, 5519. [CrossRef]

160. Juvekar, A.; Burga, L.N.; Hu, H.; Lunsford, E.P.; Ibrahim, Y.H.; Balmana, J.; Rajendran, A.; Papa, A.; Spencer, K.; Lyssiotis, C.A.; et al. Combining a PI3K inhibitor with a PARP inhibitor provides an effective therapy for BRCA1-related breast cancer. Cancer Discov. 2012, 2, 1048-1063. [CrossRef]

161. Ibrahim, Y.H.; Garcia-Garcia, C.; Serra, V.; He, L.; Torres-Lockhart, K.; Prat, A.; Anton, P.; Cozar, P.; Guzman, M.; Grueso, J.; et al. PI3K inhibition impairs BRCA1/2 expression and sensitizes BRCA-proficient triple-negative breast cancer to PARP inhibition. Cancer Discov. 2012, 2, 1036-1047. [CrossRef] [PubMed]

162. Cardnell, R.J.; Feng, Y.; Diao, L.; Fan, Y.H.; Masrorpour, F.; Wang, J.; Shen, Y.; Mills, G.B.; Minna, J.D.; Heymach, J.V.; et al. Proteomic markers of DNA repair and PI3K pathway activation predict response to the PARP inhibitor BMN 673 in small cell lung cancer. Clin. Cancer Res. 2013, 19, 6322-6328. [CrossRef]

163. Matulonis, U.A.; Wulf, G.M.; Barry, W.T.; Birrer, M.; Westin, S.N.; Farooq, S.; Bell-McGuinn, K.M.; Obermayer, E.; Whalen, C.; Spagnoletti, T.; et al. Phase I dose escalation study of the PI3kinase pathway inhibitor BKM120 and the oral poly (ADP ribose) polymerase (PARP) inhibitor olaparib for the treatment of high-grade serous ovarian and breast cancer. Ann. Oncol. 2017, 28, 512-518. [CrossRef] [PubMed]

164. Westin, S.N.; Litton, J.K.; Williams, R.A.; Shepherd, C.J.; Brugger, W.; Pease, E.J.; Soliman, P.T.; Frumovitz, M.M.; Levenback, C.F.; Sood, A.; et al. Phase I trial of olaparib (PARP inhibitor) and vistusertib (mTORC1/2 inhibitor) in recurrent endometrial, ovarian and triple negative breast cancer. J. Clin. Oncol. 2018, 36, 5504. [CrossRef]

165. Westin, S.; Litton, J.; Williams, R.; Soliman, P.; Frumovitz, M.; Schmeler, K.; Jazaeri, A.; Sood, A.; Lu, K.; Moulder, S.; et al. 391PPhase I expansion of olaparib (PARP inhibitor) and AZD5363 (AKT inhibitor) in recurrent ovarian, endometrial and triple negative breast cancer. Ann. Oncol. 2017, 28, mdx367.025. [CrossRef] 
166. Ang, J.E.; Gourley, C.; Powell, C.B.; High, H.; Shapira-Frommer, R.; Castonguay, V.; De Greve, J.; Atkinson, T.; Yap, T.A.; Sandhu, S.; et al. Efficacy of chemotherapy in BRCA1/2 mutation carrier ovarian cancer in the setting of PARP inhibitor resistance: A multi-institutional study. Clin. Cancer Res. 2013, 19, 5485-5493. [CrossRef] [PubMed]

167. Mesiano, S.; Ferrara, N.; Jaffe, R.B. Role of vascular endothelial growth factor in ovarian cancer: Inhibition of ascites formation by immunoneutralization. Am. J. Pathol. 1998, 153, 1249-1256. [CrossRef]

168. Byrne, A.T.; Ross, L.; Holash, J.; Nakanishi, M.; Hu, L.; Hofmann, J.I.; Yancopoulos, G.D.; Jaffe, R.B. Vascular endothelial growth factor-trap decreases tumor burden, inhibits ascites, and causes dramatic vascular remodeling in an ovarian cancer model. Clin. Cancer Res. 2003, 9, 5721-5728. [PubMed]

169. Hollingsworth, H.C.; Kohn, E.C.; Steinberg, S.M.; Rothenberg, M.L.; Merino, M.J. Tumor angiogenesis in advanced stage ovarian carcinoma. Am. J. Pathol. 1995, 147, 33-41. [PubMed]

170. Duncan, T.J.; Al-Attar, A.; Rolland, P.; Scott, I.V.; Deen, S.; Liu, D.T.; Spendlove, I.; Durrant, L.G. Vascular endothelial growth factor expression in ovarian cancer: A model for targeted use of novel therapies? Clin. Cancer Res. 2008, 14, 3030-3035. [CrossRef] [PubMed]

171. Norquist, B.M.; Brady, M.F.; Harrell, M.I.; Walsh, T.; Lee, M.K.; Gulsuner, S.; Bernards, S.S.; Casadei, S.; Burger, R.A.; Tewari, K.S.; et al. Mutations in Homologous Recombination Genes and Outcomes in Ovarian Carcinoma Patients in GOG 218: An NRG Oncology/Gynecol. Oncol. Group Study. Clin. Cancer Res. 2018, 24, 777-783. [CrossRef]

172. Harter, P.; Johnson, T.; Berton-Rigaud, D.; Park, S.Y.; Friedlander, M.; Del Campo, J.M.; Shimada, M.; Forget, F.; Mirza, M.R.; Colombo, N.; et al. BRCA1/2 mutations associated with progression-free survival in ovarian cancer patients in the AGO-OVAR 16 study. Gynecol. Oncol. 2016, 140, 443-449. [CrossRef] [PubMed]

173. Burger, R.A.; Brady, M.F.; Bookman, M.A.; Fleming, G.F.; Monk, B.J.; Huang, H.; Mannel, R.S.; Homesley, H.D.; Fowler, J.; Greer, B.E.; et al. Incorporation of bevacizumab in the primary treatment of ovarian cancer. N. Engl. J. Med. 2011, 365, 2473-2483. [CrossRef]

174. Perren, T.J.; Swart, A.M.; Pfisterer, J.; Ledermann, J.A.; Pujade-Lauraine, E.; Kristensen, G.; Carey, M.S.; Beale, P.; Cervantes, A.; Kurzeder, C.; et al. A phase 3 trial of bevacizumab in ovarian cancer. N. Engl. J. Med. 2011, 365, 2484-2496. [CrossRef]

175. Oza, A.M.; Cook, A.D.; Pfisterer, J.; Embleton, A.; Ledermann, J.A.; Pujade-Lauraine, E.; Kristensen, G.; Carey, M.S.; Beale, P.; Cervantes, A.; et al. Standard chemotherapy with or without bevacizumab for women with newly diagnosed ovarian cancer (ICON7): Overall survival results of a phase 3 randomised trial. Lancet Oncol. 2015, 16, 928-936. [CrossRef]

176. du Bois, A.; Floquet, A.; Kim, J.W.; Rau, J.; del Campo, J.M.; Friedlander, M.; Pignata, S.; Fujiwara, K.; Vergote, I.; Colombo, N.; et al. Incorporation of pazopanib in maintenance therapy of ovarian cancer. J. Clin. Oncol. 2014, 32, 3374-3382. [CrossRef]

177. Schreiber, R.D.; Old, L.J.; Smyth, M.J. Cancer immunoediting: Integrating immunity's roles in cancer suppression and promotion. Science 2011, 331, 1565-1570. [CrossRef]

178. Greenwald, R.J.; Freeman, G.J.; Sharpe, A.H. The B7 family revisited. Annu. Rev. Immunol. 2005, $23,515-548$. [CrossRef] [PubMed]

179. Zou, W.; Chen, L. Inhibitory B7-family molecules in the tumour microenvironment. Nat. Rev. Immunol. 2008, 8, 467-477. [CrossRef] [PubMed]

180. Okazaki, T.; Honjo, T. PD-1 and PD-1 ligands: From discovery to clinical application. Int. Immunol. 2007, 19, 813-824. [CrossRef] [PubMed]

181. Dai, Y.; Sun, C.; Feng, Y.; Jia, Q.; Zhu, B. Potent immunogenicity in BRCA1-mutated patients with high-grade serous ovarian carcinoma. J. Cell. Mol. Med. 2018. [CrossRef]

182. Le, D.T.; Durham, J.N.; Smith, K.N.; Wang, H.; Bartlett, B.R.; Aulakh, L.K.; Lu, S.; Kemberling, H.; Wilt, C.; Luber, B.S.; et al. Mismatch repair deficiency predicts response of solid tumors to PD-1 blockade. Science 2017, 357, 409-413. [CrossRef]

183. Nebot-Bral, L.; Brandao, D.; Verlingue, L.; Rouleau, E.; Caron, O.; Despras, E.; El-Dakdouki, Y.; Champiat, S.; Aoufouchi, S.; Leary, A.; et al. Hypermutated tumours in the era of immunotherapy: The paradigm of personalised medicine. Eur. J. Cancer 2017, 84, 290-303. [CrossRef] [PubMed] 
184. Strickland, K.C.; Howitt, B.E.; Shukla, S.A.; Rodig, S.; Ritterhouse, L.L.; Liu, J.F.; Garber, J.E.; Chowdhury, D.; $\mathrm{Wu}$, C.J.; D'Andrea, A.D.; et al. Association and prognostic significance of BRCA1/2-mutation status with neoantigen load, number of tumor-infiltrating lymphocytes and expression of PD-1/PD-L1 in high grade serous ovarian cancer. Oncotarget 2016, 7, 13587-13598. [CrossRef] [PubMed]

185. McAlpine, J.N.; Porter, H.; Kobel, M.; Nelson, B.H.; Prentice, L.M.; Kalloger, S.E.; Senz, J.; Milne, K.; Ding, J.; Shah, S.P.; et al. BRCA1 and BRCA2 mutations correlate with TP53 abnormalities and presence of immune cell infiltrates in ovarian high-grade serous carcinoma. Mod. Pathol. 2012, 25, 740-750. [CrossRef] [PubMed]

186. Clarke, B.; Tinker, A.V.; Lee, C.H.; Subramanian, S.; van de Rijn, M.; Turbin, D.; Kalloger, S.; Han, G.; Ceballos, K.; Cadungog, M.G.; et al. Intraepithelial T cells and prognosis in ovarian carcinoma: Novel associations with stage, tumor type, and BRCA1 loss. Mod. Pathol. 2009, 22, 393-402. [CrossRef]

187. Disis, M.L.; Patel, M.R.; Pant, S.; Hamilton, E.P.; Lockhart, A.C.; Kelly, K.; Beck, J.T.; Gordon, M.S.; Weiss, G.J.; Taylor, M.H.; et al. Avelumab (MSB0010718C; anti-PD-L1) in patients with recurrent/refractory ovarian cancer from the JAVELIN Solid Tumor phase Ib trial: Safety and clinical activity. J. Clin. Oncol. 2016, 34, 5533. [CrossRef]

188. Varga, A.; Piha-Paul, S.A.; Ott, P.A.; Mehnert, J.M.; Berton-Rigaud, D.; Morosky, A.; Zhao, G.Q.; Rangwala, R.A.; Matei, D. Pembrolizumab in patients (pts) with PD-L1-positive (PD-L1+) advanced ovarian cancer: Updated analysis of KEYNOTE-028. J. Clin. Oncol. 2017, 35, 5513. [CrossRef]

189. Brahmer, J.R.; Tykodi, S.S.; Chow, L.Q.; Hwu, W.J.; Topalian, S.L.; Hwu, P.; Drake, C.G.; Camacho, L.H.; Kauh, J.; Odunsi, K.; et al. Safety and activity of anti-PD-L1 antibody in patients with advanced cancer. N. Engl. J. Med. 2012, 366, 2455-2465. [CrossRef] [PubMed]

190. Hamanishi, J.; Mandai, M.; Ikeda, T.; Minami, M.; Kawaguchi, A.; Murayama, T.; Kanai, M.; Mori, Y.; Matsumoto, S.; Chikuma, S.; et al. Safety and Antitumor Activity of Anti-PD-1 Antibody, Nivolumab, in Patients With Platinum-Resistant Ovarian Cancer. J. Clin. Oncol. 2015, 33, 4015-4022. [CrossRef]

191. Matulonis, U.; Shapira-Frommer, R.; Santin, A.; Lisyanskaya, A.S.; Pignata, S.; Vergote, I.; Raspagliesi, F.; Sonke, G.S.; Birrer, M.; Provencher, D.; et al. Antitumor activity and safety of pembrolizumab in patients with advanced recurrent ovarian cancer: Interim results from the phase 2 KEYNOTE-100 study. J. Clin. Oncol. 2018. [CrossRef]

192. Kristeleit, R.; Davidenko, I.; Shirinkin, V.; El-Khouly, F.; Bondarenko, I.; Goodheart, M.J.; Gorbunova, V.; Penning, C.A.; Shi, J.G.; Liu, X.; et al. A randomised, open-label, phase 2 study of the IDO1 inhibitor epacadostat (INCB024360) versus tamoxifen as therapy for biochemically recurrent (CA-125 relapse)-only epithelial ovarian cancer, primary peritoneal carcinoma, or fallopian tube cancer. Gynecol. Oncol. 2017, 146, 484-490. [CrossRef] [PubMed]

193. Battaglia, A.; Fossati, M.; Buzzonetti, A.; Scambia, G.; Fattorossi, A. A robust immune system conditions the response to abagovomab (anti-idiotypic monoclonal antibody mimicking the CA125 protein) vaccination in ovarian cancer patients. Immunol. Lett. 2017, 191, 35-39. [CrossRef] [PubMed]

194. Mouw, K.W.; Konstantinopoulos, P.A. From checkpoint to checkpoint: DNA damage ATR/Chk1 checkpoint signalling elicits PD-L1 immune checkpoint activation. Br. J. Cancer 2018, 118, 933-935. [CrossRef] [PubMed]

195. Jiao, S.; Xia, W.; Yamaguchi, H.; Wei, Y.; Chen, M.K.; Hsu, J.M.; Hsu, J.L.; Yu, W.H.; Du, Y.; Lee, H.H.; et al. PARP Inhibitor Upregulates PD-L1 Expression and Enhances Cancer-Associated Immunosuppression. Clin. Cancer Res. 2017, 23, 3711-3720. [CrossRef]

196. Sato, H.; Niimi, A.; Yasuhara, T.; Permata, T.B.M.; Hagiwara, Y.; Isono, M.; Nuryadi, E.; Sekine, R.; Oike, T.; Kakoti, S.; et al. DNA double-strand break repair pathway regulates PD-L1 expression in cancer cells. Na. Commun. 2017, 8, 1751. [CrossRef]

197. Konstantinopoulos, P.A.; Waggoner, S.E.; Vidal, G.A.; Mita, M.M.; Fleming, G.F.; Holloway, R.W.; Le, L.V.; Sachdev, J.C.; Chapman-Davis, E.; Colon-Otero, G.; et al. TOPACIO/Keynote-162 (NCT02657889): A phase $1 / 2$ study of niraparib + pembrolizumab in patients (pts) with advanced triple-negative breast cancer or recurrent ovarian cancer (ROC)—Results from ROC cohort. J. Clin. Oncol. 2018, 36, 106. [CrossRef]

198. Drew, Y.; de Jonge, M.; Hong, S.H.; Park, Y.H.; Wolfer, A.; Brown, J.; Ferguson, M.; Gore, M.E.; Alvarez, R.H.; Gresty, C.; et al. An open-label, phase II basket study of olaparib and durvalumab (MEDIOLA): Results in germline BRCA-mutated (gBRCAm) platinum-sensitive relapsed (PSR) ovarian cancer (OC). Gynecol. Oncol. 2018, 149, 246-247. [CrossRef]

199. Do, K.; Doroshow, J.H.; Kummar, S. Wee1 kinase as a target for cancer therapy. Cell Cycle 2013, 12, 3159-3164. [CrossRef] [PubMed] 
200. Zhang, R.; Shi, H.; Ren, F.; Zhang, M.; Ji, P.; Wang, W.; Liu, C. The aberrant upstream pathway regulations of CDK1 protein were implicated in the proliferation and apoptosis of ovarian cancer cells. J. Ovarian Res. 2017, 10, 60. [CrossRef]

201. Zhang, M.; Dominguez, D.; Chen, S.; Fan, J.; Qin, L.; Long, A.; Li, X.; Zhang, Y.; Shi, H.; Zhang, B. WEE1 inhibition by MK1775 as a single-agent therapy inhibits ovarian cancer viability. Oncol. Lett. 2017, 14, 3580-3586. [CrossRef] [PubMed]

202. Do, K.; Wilsker, D.; Ji, J.; Zlott, J.; Freshwater, T.; Kinders, R.J.; Collins, J.; Chen, A.P.; Doroshow, J.H.; Kummar, S. Phase I Study of Single-Agent AZD1775 (MK-1775), a Wee1 Kinase Inhibitor, in Patients With Refractory Solid Tumors. J. Clin. Oncol. 2015, 33, 3409-3415. [CrossRef] [PubMed]

203. Ira, G.; Pellicioli, A.; Balijja, A.; Wang, X.; Fiorani, S.; Carotenuto, W.; Liberi, G.; Bressan, D.; Wan, L.; Hollingsworth, N.M.; et al. DNA end resection, homologous recombination and DNA damage checkpoint activation require CDK1. Nature 2004, 431, 1011-1017. [CrossRef]

204. Johnson, N.; Li, Y.C.; Walton, Z.E.; Cheng, K.A.; Li, D.; Rodig, S.J.; Moreau, L.A.; Unitt, C.; Bronson, R.T.; Thomas, H.D.; et al. Compromised CDK1 activity sensitizes BRCA-proficient cancers to PARP inhibition. Nat. Med. 2011, 17, 875-882. [CrossRef] [PubMed]

205. Karnak, D.; Engelke, C.G.; Parsels, L.A.; Kausar, T.; Wei, D.; Robertson, J.R.; Marsh, K.B.; Davis, M.A.; Zhao, L.; Maybaum, J.; et al. Combined inhibition of Wee1 and PARP1/2 for radiosensitization in pancreatic cancer. Clin. Cancer Res. 2014, 20, 5085-5096. [CrossRef]

206. Leijen, S.; van Geel, R.M.; Sonke, G.S.; de Jong, D.; Rosenberg, E.H.; Marchetti, S.; Pluim, D.; van Werkhoven, E.; Rose, S.; Lee, M.A.; et al. Phase II Study of WEE1 Inhibitor AZD1775 Plus Carboplatin in Patients With TP53-Mutated Ovarian Cancer Refractory or Resistant to First-Line Therapy Within 3 Months. J. Clin. Oncol. 2016, 34, 4354-4361. [CrossRef]

207. Lee, J.M.; Nair, J.; Zimmer, A.; Lipkowitz, S.; Annunziata, C.M.; Merino, M.J.; Swisher, E.M.; Harrell, M.I.; Trepel, J.B.; Lee, M.J.; et al. Prexasertib, a cell cycle checkpoint kinase 1 and 2 inhibitor, in BRCA wild-type recurrent high-grade serous ovarian cancer: A first-in-class proof-of-concept phase 2 study. Lancet. Oncol. 2018, 19, 207-215. [CrossRef]

208. Patch, A.M.; Christie, E.L.; Etemadmoghadam, D.; Garsed, D.W.; George, J.; Fereday, S.; Nones, K.; Cowin, P.; Alsop, K.; Bailey, P.J.; et al. Whole-genome characterization of chemoresistant ovarian cancer. Nature 2015, 521, 489-494. [CrossRef] [PubMed]

209. Drost, R.; Dhillon, K.K.; van der Gulden, H.; van der Heijden, I.; Brandsma, I.; Cruz, C.; Chondronasiou, D.; Castroviejo-Bermejo, M.; Boon, U.; Schut, E.; et al. BRCA1185delAG tumors may acquire therapy resistance through expression of RING-less BRCA1. J. Clin. Investig. 2016, 126, 2903-2918. [CrossRef]

210. Sakai, W.; Swisher, E.M.; Karlan, B.Y.; Agarwal, M.K.; Higgins, J.; Friedman, C.; Villegas, E.; Jacquemont, C.; Farrugia, D.J.; Couch, F.J.; et al. Secondary mutations as a mechanism of cisplatin resistance in BRCA2-mutated cancers. Nature 2008, 451, 1116-1120. [CrossRef] [PubMed]

211. Swisher, E.M.; Sakai, W.; Karlan, B.Y.; Wurz, K.; Urban, N.; Taniguchi, T. Secondary BRCA1 mutations in BRCA1-mutated ovarian carcinomas with platinum resistance. Cancer Res. 2008, 68, 2581-2586. [CrossRef]

212. Dhillon, K.K.; Swisher, E.M.; Taniguchi, T. Secondary mutations of BRCA1/2 and drug resistance. Cancer Sci. 2011, 102, 663-669. [CrossRef]

213. Kondrashova, O.; Nguyen, M.; Shield-Artin, K.; Tinker, A.V.; Teng, N.N.H.; Harrell, M.I.; Kuiper, M.J.; Ho, G.Y.; Barker, H.; Jasin, M.; et al. Secondary Somatic Mutations Restoring RAD51C and RAD51D Associated with Acquired Resistance to the PARP Inhibitor Rucaparib in High-Grade Ovarian Carcinoma. Cancer Discov. 2017, 7, 984-998. [CrossRef] [PubMed]

214. Kondrashova, O.; Topp, M.; Nesic, K.; Lieschke, E.; Ho, G.Y.; Harrell, M.I.; Zapparoli, G.V.; Hadley, A.; Holian, R.; Boehm, E.; et al. Methylation of all BRCA1 copies predicts response to the PARP inhibitor rucaparib in ovarian carcinoma. Nat. Commun. 2018, 9, 3970. [CrossRef] [PubMed]

215. Patel, A.G.; Sarkaria, J.N.; Kaufmann, S.H. Nonhomologous end joining drives poly(ADP-ribose) polymerase (PARP) inhibitor lethality in homologous recombination-deficient cells. Proc. Natl. Acad. Sci. USA 2011, 108, 3406-3411. [CrossRef]

216. Cao, L.; Xu, X.; Bunting, S.F.; Liu, J.; Wang, R.H.; Cao, L.L.; Wu, J.J.; Peng, T.N.; Chen, J.; Nussenzweig, A.; et al. A selective requirement for 53BP1 in the biological response to genomic instability induced by Brca1 deficiency. Mol. Cell 2009, 35, 534-541. [CrossRef] 
217. Bunting, S.F.; Callen, E.; Kozak, M.L.; Kim, J.M.; Wong, N.; Lopez-Contreras, A.J.; Ludwig, T.; Baer, R.; Faryabi, R.B.; Malhowski, A.; et al. BRCA1 functions independently of homologous recombination in DNA interstrand crosslink repair. Mol. Cell 2012, 46, 125-135. [CrossRef]

218. Yang, Z.M.; Liao, X.M.; Chen, Y.; Shen, Y.Y.; Yang, X.Y.; Su, Y.; Sun, Y.M.; Gao, Y.L.; Ding, J.; Zhang, A.; et al. Combining 53BP1 with BRCA1 as a biomarker to predict the sensitivity of poly(ADP-ribose) polymerase (PARP) inhibitors. Acta Pharmacol. Sin. 2017, 38, 1038-1047. [CrossRef] [PubMed]

219. Pennington, K.P.; Wickramanayake, A.; Norquist, B.M.; Pennil, C.C.; Garcia, R.L.; Agnew, K.J.; Taniguchi, T.; Welcsh, P.; Swisher, E.M. 53BP1 expression in sporadic and inherited ovarian carcinoma: Relationship to genetic status and clinical outcomes. Gynecol. Oncol. 2013, 128, 493-499. [CrossRef] [PubMed]

220. Noordermeer, S.M.; Adam, S.; Setiaputra, D.; Barazas, M.; Pettitt, S.J.; Ling, A.K.; Olivieri, M.; Alvarez-Quilon, A.; Moatti, N.; Zimmermann, M.; et al. The shieldin complex mediates 53BP1-dependent DNA repair. Nature 2018, 560, 117-121. [CrossRef]

221. Mirman, Z.; Lottersberger, F.; Takai, H.; Kibe, T.; Gong, Y.; Takai, K.; Bianchi, A.; Zimmermann, M.; Durocher, D.; de Lange, T. 53BP1-RIF1-shieldin counteracts DSB resection through CST- and Polalpha-dependent fill-in. Nature 2018, 560, 112-116. [CrossRef]

222. Durmus, S.; Sparidans, R.W.; van Esch, A.; Wagenaar, E.; Beijnen, J.H.; Schinkel, A.H. Breast cancer resistance protein (BCRP/ABCG2) and P-glycoprotein (P-GP/ABCB1) restrict oral availability and brain accumulation of the PARP inhibitor rucaparib (AG-014699). Pharm. Res. 2015, 32, 37-46. [CrossRef]

223. Olive, K.P.; Jacobetz, M.A.; Davidson, C.J.; Gopinathan, A.; McIntyre, D.; Honess, D.; Madhu, B.; Goldgraben, M.A.; Caldwell, M.E.; Allard, D.; et al. Inhibition of Hedgehog signaling enhances delivery of chemotherapy in a mouse model of pancreatic cancer. Science 2009, 324, 1457-1461. [CrossRef] [PubMed]

(C) 2019 by the authors. Licensee MDPI, Basel, Switzerland. This article is an open access article distributed under the terms and conditions of the Creative Commons Attribution (CC BY) license (http:/ / creativecommons.org/licenses/by/4.0/). 